\title{
Structure and floristic similarities of upper montane forests in Serra Fina mountain range, southeastern Brazil ${ }^{1}$
}

\author{
Leonardo Dias Meireles ${ }^{2,4}$ and George John Shepherd ${ }^{3}$
}

Received: January 29, 2014. Accepted: September 1, 2014

\begin{abstract}
The upper montane forests in the southern and southeastern regions of Brazil have an unusual and discontinuous geographic distribution at the top of the Atlantic coastal mountain ranges. To describe the floristic composition and structure of the Atlantic Forest near its upper altitudinal limit in southeastern Brazil, 30 plots with $10 \times 10 \mathrm{~m}$ were installed in three forest sites between 2,200 and 2,300 m.a.s.l. at Serra Fina. The floristic composition and phytosociological structure of this forest were compared with other montane and upper montane forests. In total, 704 individuals were included, belonging to 24 species, 15 families, and 19 genera. Myrsinaceae, Myrtaceae, Symplocaceae, and Cunoniaceae were the most important families, and Myrsine gardneriana, Myrceugenia alpigena, Weinmannia humilis, and Symplocos corymboclados were the most important species. The three forest sites revealed differences in the abundance of species, density, canopy height, and number of stems per individual. The upper montane forests showed structural similarities, such as lower richness, diversity, and effective number of species, and they tended to have higher total densities and total dominance per hectare to montane forests. The most important species in these upper montane forests belong to Austral-Antartic genera or neotropical and pantropical genera that are typical of montane areas. The high number of species shared by these forests suggests past connections between the vegetation in southern Brazilian high-altitude areas.
\end{abstract}

Keywords: Atlantic Rain Forest, cloud forest, Last Glacial Maximum, Mantiqueira mountain range, montane forest

\section{Introduction}

The Atlantic upper montane forest (AUMF) shows a distinct geographical distribution due to the spatial discontinuity of high-altitude areas in the Atlantic coastal mountain ranges of the south and southeastern regions of Brazil. This forest formation represents the upper altitudinal limit of the Atlantic Forest Domain and has a distinctive floristic composition and phytosociological structure in relation to forests located at intermediate and lower altitudes (Falkenberg \& Voltolini 1995; Portes \& Galvão 2002; Koehler et al. 2002; Meireles et al. 2008; Bertoncello et al. 2011; Scheer et al. 2011). These forests are equivalent to cloud forests, which typically occur in a narrow altitudinal zone, wherein topography and climate conditions favor the occurrence of clouds or fog. The clouds cover the forest belts by persistent, frequent, or seasonal frequency (Hamilton et al. 1995).

AUMF corresponds to "tropical ombrophilous cloud forest" (sensu UNESCO 1973), "tropical montane cloud forest" (sensu Hamilton et al. 1995), to "cloud forest" (sensu
Stadmüller 1987). Cloud forests are extremely important for maintaining water resources by capturing water from fog, a process that is denominated "horizontal precipitation" (Bruijnzeel \& Proctor 1995). This water, which could potentially be lost, is then retained and distinguishes cloud forests from other forest types (Stadtmüller 1987). The occurrence and extraction of water from cloud or fog increases atmospheric humidity, allowing these forests to occur in climatic regions where the matrix vegetation is predominantly drier or very seasonal (Gioda et al. 1995; Juvik \& Nullet 1995).

In high-altitude areas, climate and physical conditions, such as strong winds, low temperatures, higher rainfall, higher incidence of UV-B light, and lower atmospheric pressure have been associated with the establishment, physiognomy, structure, and floristic composition of montane forests (Lawton 1982; Flenley 1995). The fog also affects the amount of energy received by changing the quality and intensity of light, reducing the solar radiation that creates a deficit in the suppression of evaporation and evapotranspiration from these forests (Flenley 1995; Hamilton et

\footnotetext{
${ }^{1}$ Part of doctoral thesis of first author, Programa de Pós-Graduação em Biologia Vegetal, Unicamp.

${ }^{2}$ Escola de Artes, Ciências e Humanidades da Universidade de São Paulo, Gestão Ambiental, São Paulo, SP, Brasil.

${ }^{3}$ Universidade Estadual de Campinas, Departamento de Biologia Vegetal, Caixa Postal 6109, 13083-970 Campinas, SP, Brasil.

${ }^{4}$ Corresponding author: leodmeireles@gmail.com
} 
al. 1995). These conditions also favor the occurrence of avascular poikilohydric plants, such as bryophytes, lichens, and filmy ferns (Hymenophyllaceae) or arborescent ferns (Cyatheaceae and Dicksoniaceae). This is a typical feature shared by all cloud forests in the humid tropics (Stadtmüller 1987; Hamilton et al. 1995).

The physiognomic attributes of these forests include a reduction in canopy stature and number of tree layers, a high density of individuals and fewer species, a high proportion of avascular or vascular epiphytes, and a reduction of woody lianas. These are parameters that usually respond to higher altitudes in mountainous regions (Hamilton et al. 1995). In general, the trees are not tall, and they may present with a compact crown, branches, and trunks, which can be much branched. The leaves are usually simple, small, often thick, and leathery, with a smaller proportion of species containing compound leaves (Hamilton et al. 1995). In these forests, the growth of individuals is expected to be slower with shorter internodes, and the leaves often contain extra pigments, such as anthocyanins and flavonoids in their hypodermis (Flenley 1995).

AUMFs were largely ignored in the old Brazilian phytogeographical vegetation systems (Falkenberg \& Voltolini 1995). Until the 1990s, no information was published about their floristic composition or their structural and ecophysiological characteristics (Falkenberg \& Voltolini 1995; Carvalho et al. 2000; Portes \& Galvão 2002; Koehler et al. 2002; França \& Stehmann 2004; Meireles et al. 2008; Bertoncello et al. 2011; Scheer et al. 2011; Oliveira et al. 2014). This forest type in Brazil was first described by Rambo (1949) for the southern region (Falkenberg \& Voltolini 1995). In the last two decades, some phytosociological surveys of AUMFs have been conducted in south and southeastern Brazil; however, till date, such studies have only been conducted at altitudes up to 1,900 m (see Koehler et al. 2002; Meireles et al. 2008).

Hueck (1972) mentioned that the lower altitudinal limit of AUMFs in the southeastern region of Brazil is at 1,200 m.a.s.l. in the Serra do Mar mountain range and between 1,300 and 1,400 m.a.s.l. in the Serra da Mantiqueira mountain range. Meireles et al. (2008) suggested that the lower altitudinal limit in the Serra da Mantiqueira is at 1.500 m.a.s.l. On the Itatiaia Plateau, AUMFs occur up to $2,300 \mathrm{~m}$ and within fragments of more protected areas at approximately $100-200 \mathrm{~m}$ above this elevation (Hueck 1972). In the southern region of Brazil, they occur at the top of the Serra do Mar mountain at altitudes above 1,200 $\mathrm{m}$.a.s.l. They can also occur below this altitude in protected valleys in the states of Paraná and Santa Catarina and along the edge of Aparados da Serra Plateau, located in the south of Santa Catarina State along the northern boundary of the state of Rio Grande do Sul, at 700-1,700 m.a.s.l. (Falkenberg \& Voltolini 1995; Koehler et al. 2002; Portes \& Galvão 2002; Falkenberg 2003).
Falkenberg \& Voltolini (1995) suggested that AUMFs do not form a homogeneous vegetation type, but instead form a set of plant communities with relatively similar physiognomies under the influence of altitude, degree of exposure to ocean winds, local topography, variable substrate, and local microclimatic. In the present study, our goal was to examine the floristic composition and phytosociological structure of the three forest sites of the upper montane forest at Pico do Capim Amarelo in the Serra Fina mountain range, located in southeastern Brazil. We conducted statistical comparisons between AUMF and montane forests (AMF) to verify if such forests differ in terms of horizontal and vertical phytosociological structure. Variations in floristic and phytosociological structure of AUMFs over its occurrences in the southern and southeastern Brazilian coastal mountains were also analyzed to help us identify and classify these forest formations within the Atlantic Forest Domain.

\section{Material and Methods}

The Serra Fina (SF) $\left(22^{\circ} 20^{\prime}-22^{\circ} 30^{\prime} \mathrm{S}, 44^{\circ} 45^{\prime}-45^{\circ} 00^{\prime} \mathrm{W}\right)$ is one of the high-altitude areas of Serra da Mantiqueira mountain range in Itatiaia Plateau located at the triple-State geographical boundary of Minas Gerais, São Paulo, and Rio de Janeiro states in southeastern Brazil (Moreira \& Camelier 1977). The SF has a very steep relief with altitudes in the central area that range markedly over $5 \mathrm{~km}$ between 1,000 to 2,798 m.a.s.l. on the Pedra da Mina peak, which is the fourth highest peak in Brazil (Chiesse 2004). The Pico do Capim

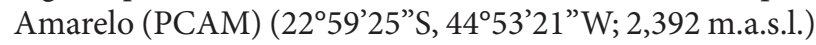
is located in the southern region of Serra Fina between the towns of Passa Quatro in Minas Gerais State and Lavrinhas in São Paulo State. The east side of PCAM has a long steep slope leading down to Vale do Paraíba (São Paulo State), and on the west side there is a gentle slope that leads down to Campo do Muro (Minas Gerais State).

The mean annual precipitation ranges from 1,500 to $1,700 \mathrm{~mm}$, and can reach about $2,400 \mathrm{~mm}$ in higher areas (Nimer 1977a; Silva \& Leite 2000). The rainfall has a seasonal distribution and is more intense in the warmer months (December-March), about 200 to $250 \mathrm{~mm}$ per month. The precipitation averages about 20 to $50 \mathrm{~mm}$ per month during the cold and dry months (June-August), but a severe drought has not been recorded (Nimer 1977a). The mean annual temperature above 1,500 m.a.s.l. ranges from 12 to $15^{\circ} \mathrm{C}$, and in the coldest quarter it is around $5-8^{\circ} \mathrm{C}$ (Safford 1999). The absolute minimum temperature in the coldest months (June-July) may be less than $0^{\circ} \mathrm{C}$, reaching between -4 to $-6^{\circ} \mathrm{C}$ in the dry season (Safford 1999; Nimer 1977a). This region may have more than 100 cloudy days per year and has a high incidence of frost, with an average of 10-30 days per year of frost (Nimer 1977a; Tubelis \& Nascimento 1980). Strong sporadic frosts may be observed, which completely freezes the forest formation. These climatic conditions correspond to subtropical cli- 
mate of altitude, classified as Cwb in the Koeppen climatic system (Martins 2000).

The route to reach the PCAM begins at 1,500 m.a.s.l., where Montane forests, candeia scrub, and subsequently high-altitude grasslands in the quartzitic rocks are replaced by high-altitude grassland in the nifelina-sienito rock at approximately 2,000 m.a.s.l. At the top of PCAM there is a small flat area consisting of rocky outcrops and high-altitude grasslands dominated mainly by the giant tussock grasses Cortaderia sp. Forest formations surrounded by shrubs are distributed along steep or flat areas below the peak where moister soils are more developed. A phytosociological survey was conducted in three forest sites of the upper montane forest around PCAM from March to September 2007. Three independent forest sites (named VP, FO, and $\mathrm{MN}$ ) were sampled by establishing 10 plots of $10 \times 10 \mathrm{~m}$ at each site, representing a total area of $3,000 \mathrm{~m}^{2}$. All individuals with a perimeter at breast height $(\mathrm{PBH})$ of $\geq 15 \mathrm{~cm}$ were sampled and had their circumference $(\mathrm{cm})$ and height (m) measured. Multi-stemmed individuals at breast height were sampled if at least one stem showed this minimal PBH criterion. Vouchers of specimens were deposited in the UEC Herbarium (Universidade Estadual de Campinas, São Paulo, Brazil).

The VP forest site $\left(22^{\circ} 26^{\prime} 08^{\prime \prime} \mathrm{S}, 44^{\circ} 51^{\prime} 27^{\prime \prime} \mathrm{W} ; 2,250\right.$ m.a.s.l.) was located in a steep area on the southeastern side, 200 meters below the PCAM summit, facing the Vale do Paraíba. The FO forest site (22 $25^{\prime} 57^{\prime \prime} S, 44^{\circ} 53^{\prime} 24^{\prime \prime} \mathrm{W} ; 2,320$ m.a.s.l.) was located in a small valley on the west side of the PCAM. The MN forest site ( $22^{\circ} 25^{\prime} 45^{\prime \prime} \mathrm{S}, 44^{\circ} 52^{\prime} 46^{\prime \prime}$ 'W; 2,280 m.a.s.l) was located about 1,000 meters to the north of the PCAM, in a region known as Maracanã. It is located in a relatively flat area and is continuous with forests that cover the east side of SF, facing the Vale do Paraíba. For more details about soil characteristics, herbaceous, and shrub strata see Meireles (2009).

To describe the forest structure, a floristic list was compiled with phytosociological parameters of the three sampling sites (Tables 1,2). The calculated parameters for the species were absolute and relative frequency, relative values of density and dominance as well as cover and importance values for each sample area and for all sample areas together (Mueller-Dombois \& Ellenberg 1974). The diversity index of Shannon-Wiener (H'), evenness ( $J$ ), and Simpson index (D) were used to analyze the floristic heterogeneity (Magurran 1988). The phytosociological parameters and diversity index were calculated using Fitopac 1.6.4 (Shepherd 2006). A correspondence analysis (CA) (Hill 1973) was performed to analyze the indirect ordination of forest sites by species abundance in order to verify the horizontal structure similarities among PCAM forest sites. Those species observed at only one site were eliminated in this analysis because the CA is very sensitive to their presence (McCune \& Grace 2002). This multivariate analysis was performed using Fitopac 1.6.4 (Shepherd 2006).
A non-parametric Kruskal-Wallis test was applied to verify statistical differences among forest sites on average tree height and diameter. A Chi-square test was performed to verify differences in the proportion of multi-stemmed individuals at breast height and the number of stems per individual among forest sites using Bioestat 5.0 (Ayres et al. 2007; Zar 1999). To verify the geographic distribution patterns of PCAM tree forest species, taxonomic literature and websites were checked and five patterns were described: (IP) species endemic to Itatiaia Plateau, (SE) species restricted to montane forests in southeastern Brazil, (SES) species that occur in the south and southeastern Brazilian coastal mountain ranges, (MA) species extending their occurrence area to montane areas in the Espinhaço Range or to the northeast and midwestern Brazilian regions, and (AN) species that occur in montane forest in the Andes.

To test for differences in horizontal and vertical structure between AMF and AUMF surveys, the structural parameters of species richness $(S)$, Shannon-Wiener index $\left(H^{\prime}\right)$, total density per hectare (DE), total dominance per hectare (DO), and effective number of species ( $\left.\mathrm{DH}^{\prime}\right)$ were listed among surveys with $\mathrm{PBH}$ ranging between 15 and $16 \mathrm{~cm}$ (Table 3). The AMF phytosociological parameters were compiled from Rodrigues et al. (1989) and Dilisch et al. (2001), and those from AUMF were compiled from Roderjan (1994), Rocha (1999), Falkenberg (2003), França \& Stehmann (2004), and Meireles et al. (2008). The effective number of species corresponds to the exponential value of the Shannon-Wiener index $\left(H^{\prime}\right)$, representing the number of species expected if their abundances were equal within the sample (Jost 2006). An analysis of principal components was performed with those phytosociological parameters to verify the similarities between AUMF and AMF surveys using Fitopac 1.6.4 (Shepherd 2006).

To test for differences in structure between AUMFs and AMFs, statistical tests were performed. AMF parameters were obtained from Dislich et al. (2001). The eight AMF surveys were conducted in the Atlantic Plateau of São Paulo State and their altitudes ranged from 800 to 1,170 m.a.s.l. The AUMF surveys were conducted in southern and southeastern Brazil and their altitudes ranged from 1,200 to 1,710 m.a.s.l. in the southern region and 1,900 to 2,300 m.a.s.l. in the southeastern region (Fig. 1). Surveys conducted in different forest fragments in the same area were considered as separate for the analyses. The structural parameters that showed normal distribution were analyzed by the $t$ tests, and by nonparametric Mann-Whitney tests (Zar 1999) for data that did not show normal distribution using Bioestat 5.0 (Ayres et al. 2007).

A second comparison was performed among AUMF surveys (Table 4). This set was composed of only AUMF forest sites to verify phytosociological structure differences between altitudinal extremes inside the same altitudinal regional gradients. Seven surveys along the extreme altitudinal gradient were conducted. One set consisting of 


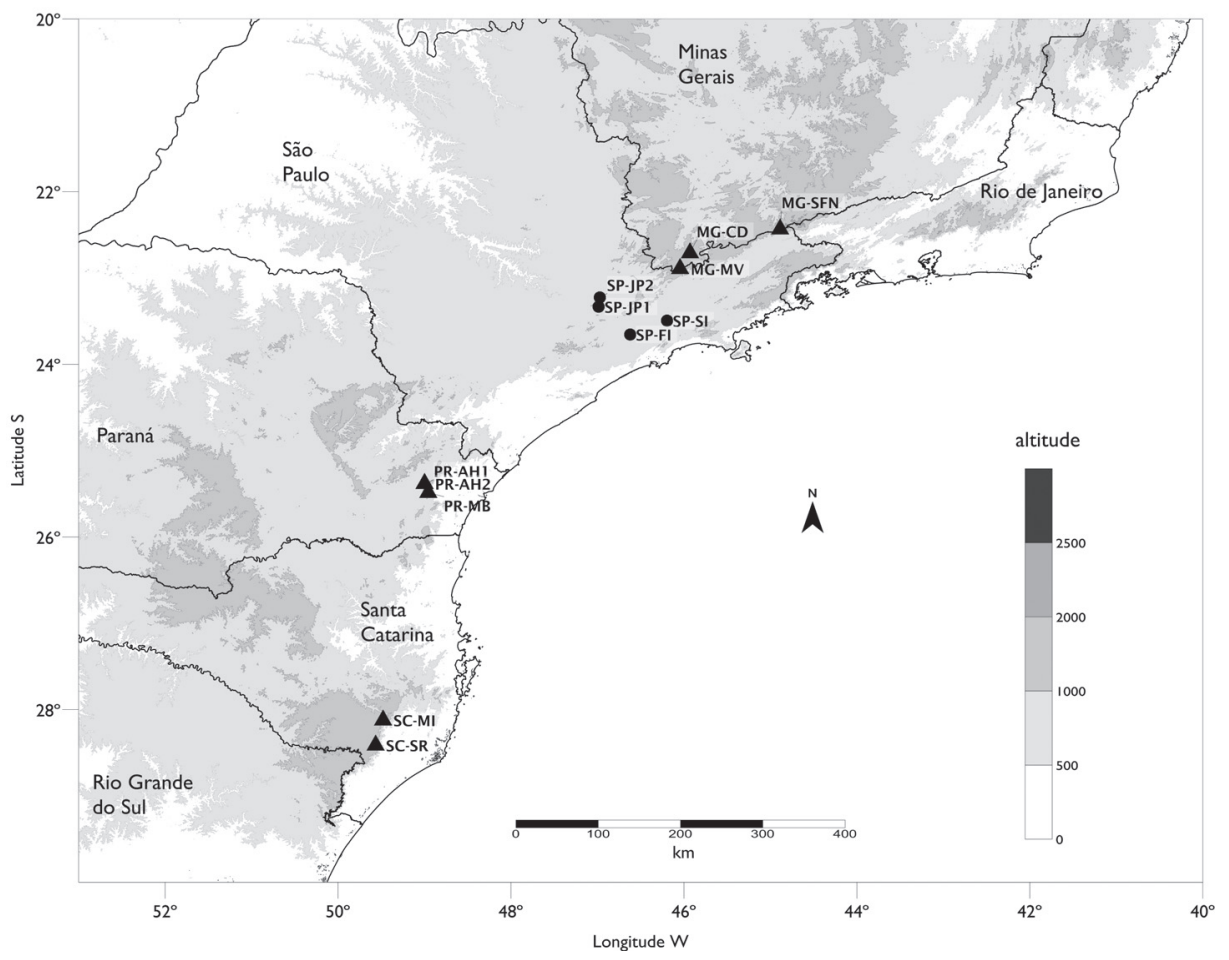

Figure 1. Geographical distribution of the Atlantic montane forest (AMF - - ) and Atlantic upper montane forests (AUMF - $\mathbf{\Delta}$ ) surveys in the southern and southeastern regions of Brazil. SC-SR and SC-MI: Falkenberg (2003), PR-MB: Rocha (1999), PR-AH1 and PR-AH2: Roderjan (1994), MG-MV: Meireles et al. (2008), MG-CD: França \& Stehmann (2004), MG-SFN: this sample, SP-FI and SP-SI: Dilisch et al. (2003), SP-JP1 and SP-JP2: Rodrigues et al. (1989).

three surveys was dominated by AUMFs at higher altitudes $(1,300-1,700$ m.a.s.l. in the south and 2,300 m.a.s.l. in the southeast), while another set comprising four surveys was dominated by AUMFs at lower altitudes $(1,200$ m.a.s.l. in the south and 1,800-1,900 m.a.s.l. in the southeast). To analyze the variability of dominant species in AUMFs, we listed the five species with the highest values of importance (IV) in each survey and compared them with the floristic table composed by Dislich et al. (2001) and the AMF surveys (Table 5). AUMFs were also quantified using the most species rich families and genera, and using the complete floristic list of surveys.

\section{Results}

A total of 704 individuals belonging to 22 tree species and 2 woody lianas distributed in 15 families and 19 genera were sampled in three forest sites around the PCAM, including the standing dead individuals (Table 1). Asteraceae (07 spp.), Symplocaceae (03 spp.), and Myrtaceae (02 spp.) were the most species rich families. Baccharis (03 spp.) was the richest genera, while Myrceugenia and Symplocos were represented by two species. Myrsinaceae, Myrtaceae, Symplocaceae, and Cunoniaceae showed the highest IV and represented $60.3 \%$ of the total IV. Asteraceae, Solanaceae, Escalloniaceae, Winteraceae, Proteaceae, Celastraceae, and Melastomataceae accounted for $28.8 \%$ of the total IV.
Aquifoliaceae, Onagraceae, and Clethraceae accounted for $1.6 \%$ of the total IV, whereas Fabaceae represented only $0.3 \%$ of the total IV.

The total density for the three forest sites was 2,346 individuals $\mathrm{ha}^{-1-}$ and the total dominance was $31.40 \mathrm{~m}^{2} \mathrm{ha}^{-1}$. The Shannon-Wiener index ( $\left.\mathrm{H}^{\prime}\right)$ was 2.367 nat individual ${ }^{-1}$, with an evenness (J) of 0.735 and Simpson index (D) of 0.146. Myrsine gardneriana had the highest IV (19.9\% of the total), relative density, and relative frequency; but its relative dominance was lower than that of $M$. alpigena and Weinmannia humilis, which together represented $26.5 \%$ of the total IV (Table 1). Escallonia laevis, Solanum itatiaiae, Symphyopappus itatiayensis, and Symplocos corymboclados had more than 30 individuals, and obtained IV between 11.6 and 28.8 , corresponding to $24.2 \%$ of the total IV. The standing dead biomass represented $8.9 \%$ of the total IV and $9.3 \%$ of the total individuals. Five species had more than 10 individuals, whereas 12 species had fewer than 10 individuals, and two species were represented by only one individual each.

Of the 24 species sampled, 13 (54\%) were present in only one of the sample areas, three $(12 \%)$ in two sample areas, and eight $(33 \%)$ in three sample areas. The CA ordination of forest sites by species abundance indicated a greater similarity between VP and MN than FO. The inertia explained by the first two axes was $44.9 \%$ (Fig. 2). M. gardneriana was abundant in all sample areas, but was strongly associated with FO as well as Baccharis dentata 
Table 1. Phytosociological parameters of individuals with CAP $\geq 15 \mathrm{~cm}$ sampled in three areas of upper montane forest of the Pico do Capim Amarelo, Serra Fina, and southeastern Brazil. AR., abbreviations used for sampled areas; C, all sample areas together; VP, facing toward to Vale do Paraíba; FO, west face below of the PCAM summit; MN, about 1,000 meters in the north of the PCAM; N.I., number of individuals; N.B., total number of stems; P.B., proportion of stems per individual; F.A., absolute frequency; De.R., relative density; Do.R., relative dominance; V.C., coverture value; F.R., relative frequency; V.I.; importance value; A.M., maximum height; D.M., maximum diameter; D.P., distribution patterns; IP, endemic to Itatiaia Plateau; SE, restricted to montane forest in southeastern Brazil; SES, species that occur in the southern and southeastern Brazilian coastal mountain ranges; MA, extend their occurrence area to montane areas in Espinhaço Range or to the northeast and midwestern Brazilian regions; and AN, species that occur in montane forest in Andes. In bold is AR where the species showed the greatest VI. In parenthesis, the species abbreviation and the collector number of Leonardo Dias Meireles.

\begin{tabular}{|c|c|c|c|c|c|c|c|c|c|c|c|c|c|}
\hline Species & D.P. & AR. & N.I. & N.B. & P.B. & F.A. & De.R. & Do.R. & V.C. & F.R. & V.I. & A.M. & D. M. \\
\hline Myrsine gardneriana A. DC. & MA & $\mathrm{C}$ & 222 & 370 & 1.6 & 96.7 & 31.5 & 14.8 & 46.3 & 13.6 & 59.9 & 10.0 & 27.0 \\
\hline \multirow[t]{3}{*}{ (M.gard. - LDM 1596) } & & VP & 36 & 53 & 1.4 & 90.0 & 18.9 & 8.2 & 27.0 & 13.4 & 40.5 & 8.5 & 20.1 \\
\hline & & FO & 136 & 239 & 1.7 & 100.0 & 43.0 & 29.7 & 72.7 & 12.7 & 85.4 & 5.0 & 22.7 \\
\hline & & $\mathrm{MN}$ & 50 & 78 & 1.5 & 100.0 & 25.4 & 13.7 & 39.1 & 14.7 & 53.8 & 10.0 & 27.0 \\
\hline Myrceugenia alpigena (DC.) Landrum & MA & $\mathrm{C}$ & 83 & 156 & 1.8 & 66.7 & 11.8 & 21.8 & 33.6 & 9.4 & 43.0 & 10.0 & 48.9 \\
\hline \multirow[t]{3}{*}{ (M.alpig. - LDM 1661) } & & VP & 17 & 26 & 1.5 & 80.0 & 8.9 & 7.4 & 16.3 & 11.9 & 28.3 & 9.0 & 25.3 \\
\hline & & $\mathrm{FO}$ & 3 & 19 & 6.3 & 30.0 & 1.0 & 4.1 & 5.0 & 3.8 & 8.8 & 5.0 & 23.3 \\
\hline & & MN & 63 & 111 & 1.7 & 90.0 & 32.0 & 52.0 & 84.0 & 13.2 & 97.3 & 10.0 & 48.9 \\
\hline Weinmannia humilis Engl. & SES & $\mathrm{C}$ & 59 & 71 & 1.2 & 46.7 & 8.4 & 21.8 & 30.2 & 6.5 & 36.7 & 13.0 & 54.4 \\
\hline \multirow[t]{3}{*}{ (W.hum. - LDM 1483) } & & VP & 49 & 61 & 1.2 & 80.0 & 25.7 & 47.3 & 73.0 & 11.9 & 84.9 & 13.0 & 54.4 \\
\hline & & $\mathrm{FO}$ & 1 & 1 & 1.0 & 10.0 & 0.3 & 0.3 & 0.6 & 1.3 & 1.8 & 3.0 & 8.3 \\
\hline & & $\mathrm{MN}$ & 9 & 9 & 1.0 & 50.0 & 4.6 & 2.6 & 7.2 & 7.4 & 14.6 & 11.0 & 15.9 \\
\hline Symplocos corymboclados Brand & SES & $\mathrm{C}$ & 50 & 56 & 1.1 & 60.0 & 7.1 & 13.3 & 20.4 & 8.4 & 28.8 & 11.0 & 31.9 \\
\hline \multirow[t]{3}{*}{ (S.cory. - LDM 1697) } & & VP & 35 & 38 & 1.1 & 100.0 & 18.3 & 22.3 & 40.6 & 14.9 & 55.5 & 11.0 & 31.9 \\
\hline & & $\mathrm{FO}$ & 14 & 17 & 1.2 & 70.0 & 4.4 & 13.7 & 18.1 & 8.9 & 27.0 & 7.0 & 26.3 \\
\hline & & $\mathrm{MN}$ & 1 & 1 & 1.0 & 10.0 & 0.5 & 1.3 & 1.8 & 1.5 & 3.3 & 7.0 & 22.9 \\
\hline \multirow[t]{4}{*}{ Mortas } & - & C & 66 & 87 & 1.3 & 93.3 & 9.4 & 4.4 & 13.7 & 13.1 & 26.8 & 8.0 & 18.9 \\
\hline & & VP & 23 & 23 & 1.0 & 100.0 & 12.0 & 3.4 & 15.5 & 14.9 & 30.4 & 7.0 & 18.9 \\
\hline & & $\mathrm{FO}$ & 23 & 39 & 1.7 & 100.0 & 7.3 & 6.4 & 13.7 & 12.7 & 26.4 & 5.0 & 8.2 \\
\hline & & $\mathrm{MN}$ & 20 & 20 & 1.0 & 90.0 & 10.2 & 4.2 & 14.4 & 11.8 & 26.1 & 8.0 & 17.8 \\
\hline Symphyopappus itatiayensis (Hieron.) & SES & $\mathrm{C}$ & 56 & 73 & 1.3 & 30.0 & 8.0 & 5.1 & 13.1 & 4.2 & 17.3 & 6.0 & 19.0 \\
\hline R.M. King \& H. Rob. (Sy.itat. - LDM 2336) & & FO & 56 & 73 & 1.3 & 90.0 & 17.7 & 23.4 & 41.1 & 11.4 & 52.5 & 6.0 & 19.0 \\
\hline Solanum itatiaiae Glaz. ex Edmonds & IP & $\mathrm{C}$ & 34 & 41 & 1.2 & 56.7 & 4.8 & 2.4 & 7.2 & 7.9 & 15.2 & 10.0 & 17.2 \\
\hline \multirow[t]{3}{*}{ (So.itat. - LDM 2699) } & & VP & 9 & 13 & 1.4 & 60.0 & 4.7 & 1.9 & 6.7 & 9.0 & 15.6 & 10.0 & 16.5 \\
\hline & & $\mathrm{FO}$ & 11 & 11 & 1.0 & 50.0 & 3.5 & 1.3 & 4.8 & 6.3 & 11.2 & 4.5 & 8.0 \\
\hline & & MN & 14 & 17 & 1.2 & 60.0 & 7.1 & 3.7 & 10.8 & 8.8 & 19.6 & 9.0 & 17.2 \\
\hline Escallonia laevis Sleumer & SE & $\mathrm{C}$ & 31 & 51 & 1.6 & 33.3 & 4.4 & 2.5 & 6.9 & 4.7 & 11.6 & 6.0 & 23.6 \\
\hline (LDM 2337) & & FO & 31 & 51 & 1.6 & 100.0 & 9.8 & 11.5 & 21.3 & 12.7 & 34.0 & 6.0 & 23.6 \\
\hline Symplocos itatiaiae Wawra & SE & C & 9 & 11 & 1.2 & 26.7 & 1.3 & 3.8 & 5.1 & 3.7 & 8.8 & 12.0 & 33.6 \\
\hline \multirow[t]{3}{*}{ (LDM 2505) } & & VP & 3 & 5 & 1.6 & 30.0 & 1.6 & 2.9 & 4.5 & 4.5 & 9.0 & 9.0 & 33.6 \\
\hline & & $\mathrm{FO}$ & 1 & 1 & 1.0 & 10.0 & 0.3 & 0.2 & 0.5 & 1.3 & 1.8 & 5.0 & 6.7 \\
\hline & & MN & 5 & 5 & 1.0 & 40.0 & 2.5 & 7.2 & 9.7 & 5.9 & 15.6 & 12.0 & 33.4 \\
\hline Drimys brasiliensis Miers & MA & $\mathrm{C}$ & 14 & 17 & 1.2 & 33.3 & 2.0 & 1.8 & 3.8 & 4.7 & 8.5 & 9.0 & 21.6 \\
\hline \multirow[t]{2}{*}{ (D.bras. - LDM 2422) } & & VP & 8 & 8 & 1.0 & 50.0 & 4.2 & 2.8 & 7.0 & 7.5 & 14.4 & 9.0 & 21.6 \\
\hline & & $\mathrm{MN}$ & 6 & 9 & 1.5 & 50.0 & 3.1 & 1.8 & 4.8 & 7.4 & 12.2 & 9.0 & 16.5 \\
\hline Roupala rhombifolia Mart. ex Meisn. & MA & C & 16 & 25 & 1.5 & 26.7 & 2.3 & 1.8 & 4.1 & 3.7 & 7.8 & 9.0 & 25.1 \\
\hline \multirow[t]{3}{*}{ (R.rho. $-N R$ ) } & & VP & 3 & 4 & 1.3 & 10.0 & 1.6 & 1.6 & 3.2 & 1.5 & 4.7 & 8.0 & 25.1 \\
\hline & & $\mathrm{FO}$ & 5 & 11 & 2.2 & 10.0 & 1.6 & 1.7 & 3.2 & 1.3 & 4.5 & 3.0 & 14.8 \\
\hline & & MN & 8 & 10 & 1.2 & 60.0 & 4.1 & 2.1 & 6.2 & 8.8 & 15.0 & 9.0 & 14.7 \\
\hline
\end{tabular}


Table 1. Continuation.

\begin{tabular}{|c|c|c|c|c|c|c|c|c|c|c|c|c|c|}
\hline Species & D.P. & AR. & N.I. & N.B. & P.B. & F.A. & De.R. & Do.R. & V.C. & F.R. & V.I. & A.M. & D. M. \\
\hline Maytenus boaria Molina & $\mathrm{AN}$ & $\mathrm{C}$ & 11 & 11 & 1.0 & 20.0 & 1.6 & 2.3 & 3.9 & 2.8 & 6.7 & 7.0 & 38.2 \\
\hline \multirow[t]{3}{*}{ (M.boar. - LDM 1846) } & & $\mathrm{VP}$ & 1 & 1 & 1.0 & 10.0 & 0.5 & 0.2 & 0.8 & 1.5 & 2.2 & 5.0 & 11.0 \\
\hline & & $\mathrm{FO}$ & 3 & 3 & 1.0 & 20.0 & 1.0 & 2.3 & 3.2 & 2.5 & 5.7 & 6.0 & 16.4 \\
\hline & & MN & 7 & 7 & 1.0 & 30.0 & 3.6 & 5.0 & 8.6 & 4.4 & 13.0 & 7.0 & 38.2 \\
\hline Tibouchina hospita Cogn. & SES & $\mathrm{C}$ & 14 & 21 & 1.5 & 26.7 & 2.0 & 0.6 & 2.5 & 3.7 & 6.3 & 6.0 & 12.3 \\
\hline \multirow[t]{2}{*}{ (T.hosp. - LDM 1481) } & & FO & 12 & 18 & 1.5 & 60.0 & 3.8 & 2.1 & 5.9 & 7.6 & 13.5 & 4.5 & 12.3 \\
\hline & & MN & 2 & 3 & 1.5 & 20.0 & 1.0 & 0.3 & 1.3 & 2.9 & 4.2 & 6.0 & 8.9 \\
\hline Baccharis dentata (Vell.) G.M. Barroso & MA & $\mathrm{C}$ & 10 & 11 & 1.1 & 26.7 & 1.4 & 0.4 & 1.8 & 3.7 & 5.5 & 7.0 & 9.2 \\
\hline \multirow[t]{2}{*}{ (B.dent. - LDM 2989) } & & $\mathrm{VP}$ & 1 & 2 & 2.0 & 10.0 & 0.5 & 0.2 & 0.7 & 1.5 & 2.2 & 7.0 & 9.2 \\
\hline & & FO & 9 & 9 & 1.0 & 70.0 & 2.9 & 1.3 & 4.1 & 8.9 & 13.0 & 5.0 & 8.6 \\
\hline Ilex taubertiana Loes. & SES & C & 4 & 4 & 1.0 & 10.0 & 0.6 & 0.6 & 1.1 & 1.4 & 2.5 & 12.0 & 22.0 \\
\hline (LDM 3065) & & $\mathrm{MN}$ & 4 & 4 & 1.0 & 30.0 & 2.0 & 1.7 & 3.7 & 4.4 & 8.1 & 12.0 & 22.0 \\
\hline $\begin{array}{c}\text { Dasyphyllum leptacanthum (Gardner) } \\
\text { Cabrera }\end{array}$ & SE & $\mathrm{C}$ & 4 & 10 & 2.5 & 6.7 & 0.6 & 0.6 & 1.2 & 0.9 & 2.1 & 10.0 & 20.4 \\
\hline (LDM 2295) & & $\mathrm{MN}$ & 4 & 10 & 2.5 & 20.0 & 2.0 & 1.9 & 3.9 & 2.9 & 6.9 & 10.0 & 20.4 \\
\hline Myrceugenia ovata (Hook. \& Arn.) O. Berg & $\mathrm{AN}$ & $\mathrm{C}$ & 3 & 8 & 2.6 & 10.0 & 0.4 & 0.2 & 0.6 & 1.4 & 2.0 & 3.0 & 10.8 \\
\hline (LDM 1681) & & FO & 3 & 8 & 2.6 & 30.0 & 1.0 & 0.8 & 1.8 & 3.8 & 5.6 & 3.0 & 10.8 \\
\hline Baccharis grandimucronata Teodoro & SES & $\mathrm{C}$ & 5 & 8 & 1.6 & 6.7 & 0.7 & 0.1 & 0.8 & 0.9 & 1.8 & 3.2 & 7.3 \\
\hline (LDM 1635) & & FO & 5 & 8 & 1.6 & 20.0 & 1.6 & 0.6 & 2.2 & 2.5 & 4.7 & 3.2 & 7.3 \\
\hline Symplocos falcata Brand & SE & $\mathrm{C}$ & 2 & 2 & 1.0 & 6.7 & 0.3 & 0.5 & 0.8 & 0.9 & 1.7 & 9.0 & 23.5 \\
\hline (LDM 2258) & & MN & 2 & 2 & 1.0 & 20.0 & 1.0 & 1.4 & 2.5 & 2.9 & 5.4 & 9.0 & 23.5 \\
\hline Piptocarpha organensis Cabrera & SES & $\mathrm{C}$ & 2 & 2 & 1.0 & 6.7 & 0.3 & 0.4 & 0.7 & 0.9 & 1.6 & 9.0 & 17.2 \\
\hline (LDM 3172) & & $\mathrm{MN}$ & 2 & 2 & 1.0 & 20.0 & 1.0 & 1.2 & 2.2 & 2.9 & 5.1 & 9.0 & 17.2 \\
\hline Pentacalia desiderabilis (Velloso) Cuatrec. & MA & $\mathrm{C}$ & 3 & 3 & 1.0 & 6.7 & 0.4 & 0.1 & 0.5 & 0.9 & 1.5 & 8.0 & 7.0 \\
\hline (LDM 2502) & & VP & 3 & 3 & 1.0 & 20.0 & 1.6 & 0.2 & 1.8 & 3.0 & 4.8 & 8.0 & 7.0 \\
\hline Fuchsia regia (Vell.) Munz & SES & $\mathrm{C}$ & 2 & 2 & 1.0 & 6.7 & 0.3 & 0.2 & 0.5 & 0.9 & 1.4 & 7.0 & 15.2 \\
\hline (LDM 1471) & & VP & 2 & 2 & 1.0 & 20.0 & 1.1 & 0.5 & 1.5 & 3.0 & 4.5 & 7.0 & 15.2 \\
\hline Clethra scabra Pers. & $\mathrm{AN}$ & $\mathrm{C}$ & 1 & 2 & 2.0 & 3.3 & 0.1 & 0.5 & 0.6 & 0.5 & 1.1 & 11.0 & 24.1 \\
\hline (LDM 1715) & & VP & 1 & 2 & 2.0 & 10.0 & 0.5 & 1.1 & 1.6 & 1.5 & 3.1 & 11.0 & 24.1 \\
\hline Senna itatiaiae H.S. Irwin \& Barneby & IP & $\mathrm{C}$ & 2 & 5 & 2.5 & 3.3 & 0.3 & 0.1 & 0.4 & 0.5 & 0.9 & 3.5 & 8.4 \\
\hline (LDM 2306) & & FO & 2 & 5 & 2.5 & 10.0 & 0.6 & 0.5 & 1.2 & 1.3 & 2.4 & 3.5 & 8.4 \\
\hline Baccharis glaziovii Baker & SES & $\mathrm{C}$ & 1 & 1 & 1.0 & 3.3 & 0.1 & 0.0 & 0.2 & 0.5 & 0.6 & 2.8 & 6.4 \\
\hline (LDM 2563) & & FO & 1 & 1 & 1.0 & 10.0 & 0.3 & 0.2 & 0.5 & 1.3 & 1.7 & 2.8 & 6.4 \\
\hline
\end{tabular}

and Tibouchina hospita. Weinmannia humilis and Symplocos corymboclados were associated with VP, Maytenus boaria and M. alpigena were associated with $\mathrm{MN}$, whereas Drimys brasiliensis and Symplocos itatiaiae had similar abundances between them.

The FO site showed the highest density (316 individuals) and species-level richness (16 spp.) compared to the MN site (197 individuals and 14 spp.) and the VP site (191 individuals and $13 \mathrm{spp}$.). The density of individuals in FO was about 1.6 times higher than in VP and $\mathrm{MN}$, but FO showed the lowest dominance (Table 2). The average height $(H=311.9, P<0.0001)$ and diameter $(H=126.2313, P<$
0.0001) of tree stems in FO were significantly lower than $\mathrm{VP}$ and MN, which had no significant differences between them. The MN and FO sites were similar in terms of the proportion of multi-stemmed individuals at breast height, $29.9 \%$ and $29.1 \%$ respectively, whereas in VP it was $21.4 \%$. However, the proportion of multi-stemmed individuals at breast height among the sites did not show statistical differences $\left(\chi^{2}=2.647, P=0.2663, \mathrm{DF}=2\right)$, but FO showed a higher proportion of stems per individual than the other sites $\left(\chi^{2}=14.906, P=0.0006, \mathrm{DF}=2\right)$. The Shannon-Wiener $\left(H^{\prime}\right)$ and evenness $(J)$ were lower in FO than in VP and MN, whereas the Simpson index (D) was higher in FO. 


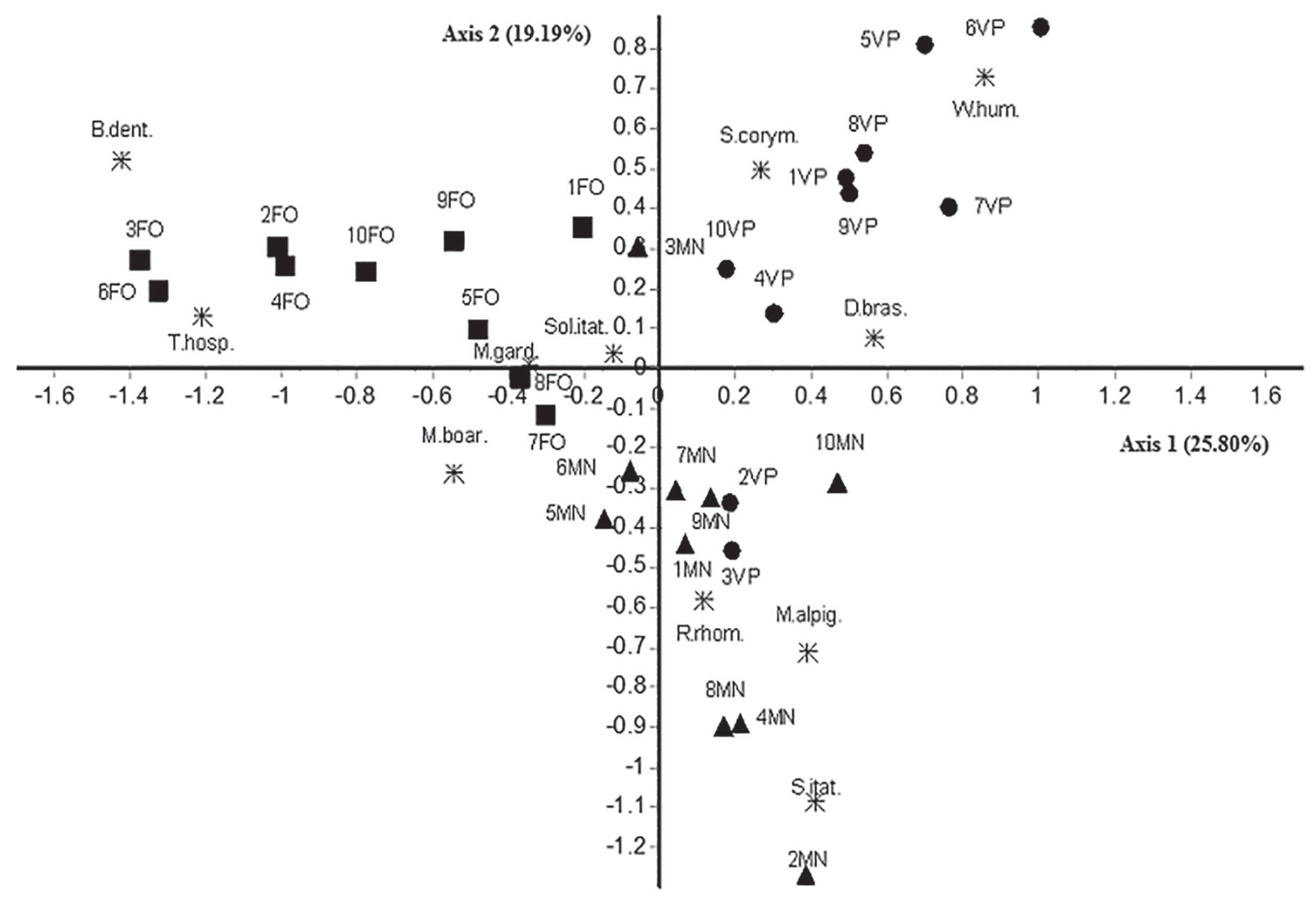

Figure 2. Correspondence analysis by the abundance of species in the upper montane forest for the three sample areas at Serra Fina, southeastern Brazil. VP ( $)$, facing toward to Vale do Paraíba; FO $(\mathbf{\Delta})$, west face below of the PCAM top; and MN ( $\boldsymbol{\square})$, about 1,000 meters in the north of the PCAM. The species acronyms are in Table 1.

Table 2. Phytosociological parameters for the three sampled areas at the Pico do Capim Amarelo, Serra Fina, southeastern Brazil. VP, facing toward to Vale do Paraíba; FO, west face below of the PCAM summit; MN, about 1,000 meters the north of the PCAM at Maracanã; N.I., number of sampled individuals; I. Mstem, number of multi-stemmed individuals; N. Stem, total number of stems; M. Stem, median number of stems by individual; Density, individuals ha ${ }^{-1}$; Dominance, ${ }^{2}$ $\mathrm{ha}^{-1}$; H. Max., maximum height of individuals in meters; H.Med., average height of individuals in meters; CAP Max., cm CAP Med., cm; Shannon, Shannon-Weiner index; J, equability index; D, Simpson index.

\begin{tabular}{|c|c|c|c|c|}
\hline Parameters & Total & $\mathrm{VP}(2,250 \mathrm{~m})$ & $\mathrm{FO}(2,320 \mathrm{~m})$ & $\mathrm{MN}(2,280 \mathrm{~m})$ \\
\hline Families & 19 & 11 & 11 & 11 \\
\hline Genera & 15 & 12 & 12 & 12 \\
\hline Species & 24 & 13 & 16 & 14 \\
\hline N.I. & 704 & 191 & 316 & 197 \\
\hline I. Mstem & 192 & 41 & 92 & 59 \\
\hline N.Stem & 1,144 & 310 & 514 & 320 \\
\hline M.Stem & 1.62 & 1.28 & 1.62 & 1.40 \\
\hline Density & 2,346 & 1,910 & 3,160 & 1,970 \\
\hline Dominance & 31.40 & 41.55 & 20.67 & 32.0 \\
\hline H. Max. & 13.0 & 13.0 & 7.0 & 12.0 \\
\hline H. Med. & 5.38 & 7.04 & 3.64 & 6.58 \\
\hline CAP Max. & 54.43 & 54.43 & 26.26 & 48.91 \\
\hline CAP Med. & 11.15 & 14.46 & 8.29 & 12.51 \\
\hline $\mathrm{H}^{\prime}$ & 2.367 & 2.048 & 1.919 & 2.047 \\
\hline $\mathrm{J}$ & 0.735 & 0.776 & 0.677 & 0.756 \\
\hline $\mathrm{D}$ & 0.146 & 0.158 & 0.235 & 0.186 \\
\hline
\end{tabular}


Table 3. Phytosociological parameters for the Atlantic montane forest (AMF) and Atlantic upper montane forests (AUMF) surveys in the southern and southeastern regions of Brazil. Abbr, abbreviation of sample area; $\mathrm{PBH}$, perimeter at breast height; $\mathrm{N}$, number of sampled individuals; $\mathrm{S}$, species richness; $\mathrm{H}$; Shannon-Weiner index; $\mathrm{D}_{\mathrm{H}}$, number of species expected by log of $\mathrm{H}^{\prime}$; DE, total density per hectare; DO, total dominance per hectare; Alt, altitude of sample area; and F.V.T., type of forest formation. MI-SC and RR-SC, Falkenberg (2003); MB-PR, Rocha (1999); AH1-PR and AH2-PR, Roderjan (1994); MV-MG, Meireles et al. (2008); CD-MG, França \& Stehmann (2004); SF-MG, this sample; FI1-SP, FI2-SP, FI3-SP, SI1-SP, SI2-SP, and SI3-SP, Dilisch et al. (2003); and SJ1-SP and SJ2-SP, Rodrigues et al. (1989).

\begin{tabular}{|c|c|c|c|c|c|c|c|c|c|c|}
\hline Surveys & Abbr. & $\mathrm{PBH}$ & $\mathrm{N}$ & $\mathrm{S}$ & $\mathrm{H}^{\prime}$ & $\mathrm{D}_{\mathrm{H}}{ }^{\prime}$ & $\mathrm{DE}$ & $\mathrm{DO}$ & Alt. & F.V.T. \\
\hline Morro da Igreja & MI-SC & 16.0 & 717 & 13 & 0.93 & 2.53 & 3,180 & 81.06 & 1710 & AUMF \\
\hline Rio do Rastro & RR-SC & 16.0 & 719 & 16 & 1.58 & 4.85 & 2,824 & 56.70 & 1400 & AUMF \\
\hline Marumbi & MB-PR & 10.0 & 321 & 29 & 2.91 & 18.36 & 4,012 & 35.24 & 1385 & AUMF \\
\hline Anhangava & AH1-PR & 10.0 & 706 & 25 & 2.22 & 9.21 & 4,418 & 29.29 & 1350 & AUMF \\
\hline Anhangava & $\mathrm{AH} 2-\mathrm{PR}$ & 10.0 & 564 & 43 & 3.18 & 24.05 & 2,169 & 41.28 & 1200 & AUMF \\
\hline Monte Verde & MV-MG & 15.0 & 1,191 & 66 & 3.28 & 26.58 & 3,403 & 37.68 & 1940 & AUMF \\
\hline Camanducaia & CD-MG & 15.0 & 1,501 & 58 & 2.90 & 18.17 & 2,001 & 48.12 & 1900 & AUMF \\
\hline Serra Fina & SF-MG & 15.0 & 704 & 24 & 2.36 & 10.59 & 2,346 & 31.40 & 2300 & AUMF \\
\hline Fontes do Ipiranga & FI1-SP & 15.7 & 500 & 123 & 4.28 & 72.24 & 1,604 & 20.00 & 800 & AUMF \\
\hline Fontes do Ipiranga & FI2-SP & 15.7 & 508 & 123 & 4.14 & 62.80 & 1,506 & 33.50 & 800 & AUMF \\
\hline Fontes do Ipiranga & FI3-SP & 15.0 & 360 & 85 & 3.85 & 47.00 & 1,488 & 26.00 & 800 & AMF \\
\hline Serra do Itapety & SI1-SP & 15.0 & 480 & 97 & 3.80 & 44.70 & 1,731 & 41.10 & $\mathrm{NI}$ & AMF \\
\hline Serra do Itapety & SI2-SP & 15.0 & 480 & 80 & 3.45 & 31.50 & 2,829 & 36.20 & $\mathrm{NI}$ & AMF \\
\hline Serra do Itapety & SI3-SP & 15.0 & 480 & 67 & 3.30 & 27.12 & 1,914 & 9.20 & $\mathrm{NI}$ & $\mathrm{AMF}$ \\
\hline Serra do Japi & SJ1-SP & 15.7 & 182 & 59 & 3.51 & 33.45 & 1,516 & 50.24 & 1170 & AMF \\
\hline Serra do Japi & SJ2-SP & 15.7 & 464 & 57 & 3.41 & 30.26 & 3,866 & 68.67 & 870 & $\mathrm{AMF}$ \\
\hline
\end{tabular}

AUMFs showed distinct horizontal structure when compared to AMFs (Table 3). AUMFs had lower richness (S) $(t=-4.5109, P=0.0002, \mathrm{GL}=14)$, lower effective number of species $\left(\mathrm{DH}^{\prime}\right)(t=-3.5209, P=0.0017, \mathrm{GL}=14)$, and lower diversity according to the Shannon-Wiener index $\left(\mathrm{H}^{\prime}\right)$ $(U=0.00, \mathrm{Z}(\mathrm{U})=3.607, P=0.0004)$; however, the total density per hectare was significantly higher when SJ2-SP (DE) was excluded $(t=3.429, P=0.0026, \mathrm{GL}=14)$. For total dominance per hectare, no significant difference was observed $(t=1.0677, P=0.1518, \mathrm{GL}=14)$. These parameters in the principal component analysis explained $85.2 \%$ of variance in the two first axes (Fig. 3).

Among AUMF surveys, a gradient was observed between AUMFs at lowest altitudes and AUMFs at higher altitudes. Statistically significant differences were observed for species richness, maximum height of the canopy, diversity index of Shannon-Wiener and maximum diameter. In AUMFs at higher altitudes, one or two tree strata were observed, whereas two or three strata were observed in AUMFs at lower altitudes (Table 4). The number of species (S) ranged from 13 to 29 for AUMFs at higher altitudes and from 43 to 58 for AUMFs at lower altitudes $(F=63.5808, P<0.00001)$. The maximum height of the canopy (Amax) ranged from 7 to $13 \mathrm{~m}$ in the AUMFs at higher altitudes and from 12 to $22 \mathrm{~m}$ in AUMF at lower altitudes $(F=9.5716, P=0.0125)$.

The diversity index of Shannon-Wiener $\left(H^{\prime}\right)$ ranged from 0.93 to 2.91 nat individual ${ }^{-1}$ in AUMF at higher altitudes and 2.90 to 3.18 nat individual ${ }^{-1}$ in AUMF at lower altitudes and were significantly different in nonparametric tests $(H=6.0357, P=0.0140)$. The maximum diameter
(Dmax) ranged from 26.26 to $54.43 \mathrm{~cm}$ in AUMFs at higher altitude, and from 49.6 to $130 \mathrm{~cm}$ in AUMFs at lower altitude $(H=4.3214, P=0.0376)$. The total density per hectare $(\mathrm{DE})$ and the total dominance per hectare (DO) for AUMFs at lower altitudes ranged from 2,001 to 3,403 individuals $\mathrm{ha}^{-1}$ and 20.67 to $81.06 \mathrm{~m}^{2} \mathrm{ha}^{-1}$, respectively, and 1,910 to 4,418 individuals $\mathrm{ha}^{-1}$ and 39.6 to $48.12 \mathrm{~m}^{2} \mathrm{ha}^{-1}$ in AUMFs at higher altitudes; but both were not different (DE: $F=0.3460$, $P=0.5761$; and DO: $H=0.3214, P=0.5708)$.

AUMF at Serra da Mantiqueira mountain range, in the southeastern region, and Serra do Mar mountain range, in the south region, showed a strong floristic similarity in family, genera, and species level. In addition to the five species with the greatest IV in the upper montane forest surveys (Table 5), we observed 26 species belonging to 20 genera and 12 families. They represented $65 \%$ of the total number of species in the scenario of greater richness, which would correspond to 40 species. The most species-rich families with the greatest IV were Myrtaceae (10 spp.), Lauraceae (03 spp.), and Asteraceae and Winteraceae (02 spp.). The richest genera were Myrceugenia (05 spp.), Ocotea (03 spp.), and Drimys (02 spp.). Six species were present in more than one survey, representing $23 \%$ of the total species observed in the five classes with highest IV. Among the surveys of upper montane forest, 187 sampled tree species belong to 79 genera and 41 families, which were above 1,500 meters in the southeastern region and above 1,300 meters in the southern region. Baccharis (09 spp.), Eugenia (07 spp.), Ilex (05 spp.), Ocotea (09 spp.), Maytenus (05 spp.), Miconia (06 spp.), Myrceugenia (11 spp.), Myrcia (11 spp.), Myrsine (04 


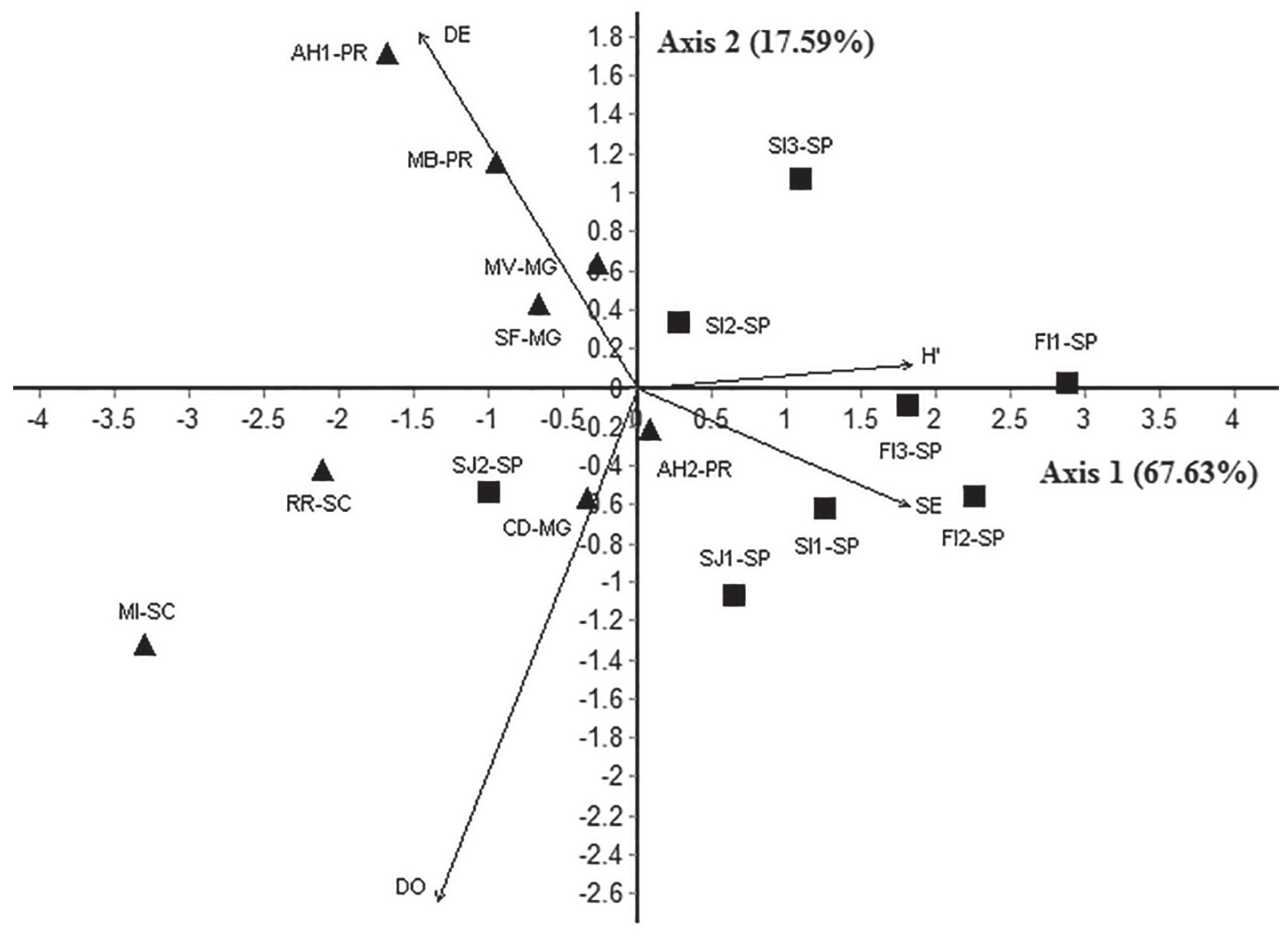

Figure 3. Principal component analysis of phytosociological parameters of the Atlantic montane forest (AMF $\boldsymbol{\Delta}$ ) and Atlantic upper montane forests (AUMF $\boldsymbol{\square}$ ) surveys in the southern and southeastern regions of Brazil. H', Shannon-Wiener index; SE, number of species expected by log of H'; DE, total density per hectare; and DO, total dominance per hectare. MI-SC and RR-SC, Falkenberg (2003); MB-PR, Rocha (1999); AH1-PR and AH2-PR, Roderjan (1994); MV-MG, Meireles et al. (2008); CD-MG, França \& Stehmann (2004); SF-MG, this sample; FI1-SP, FI2-SP, FI3-SP, SI1-SP, SI2-SP, and SI3-SP, Dilisch et al. (2003); SJ1-SP and SJ2-SP, Rodrigues et al. (1989).

Table 4. Phytosociological parameters for the Atlantic upper montane forests at higher altitude (AUMF at higher altitude, HA), and Atlantic upper montane forests at lower altitude (AUMF at lower altitude, LA) surveys in the southern and southeastern regions of Brazil. Area, sampled area; N, number of individuals sampled; S, species richness; H', Shannon-Weiner index; DE, total density per hectare; DO, total dominance per hectare; Dma, maximum diameter sampled; Dme, minimum diameter sampled; Ama, maximum height of individuals; Ame, median height of individuals; Str, number of forest strata; and Fr, type of forest formation. M. da Igreja and Rio do Rastro, Falkenberg (2003); Marumbi, Rocha (1999); Anhang. 1300 and Anhang. 1200, Roderjan (1994); Serra Fina VP, FO, MN, this sample; M. Verde 1900 and M. Verde 1800, Meireles et al. (2008); Camanducaia, França \& Stehmann (2004).

\begin{tabular}{|c|c|c|c|c|c|c|c|c|c|c|c|c|}
\hline Surveys & Area & $\mathrm{N}$ & S & $\mathrm{H}^{\prime}$ & $\mathrm{DE}$ & DO & Dma & Dme & Ama & Ame & Str & Fr \\
\hline M. da Igreja & 0.20 & 717 & 13 & 0.937 & 3,180 & 81.1 & 51.0 & 15.0 & 8.0 & 6.3 & 1 & $\mathrm{HA}$ \\
\hline Rio do Rastro & 0.22 & 719 & 16 & 1.584 & 2,824 & 56.7 & 42.0 & 13.0 & 9.0 & 7.3 & 1 & $\mathrm{HA}$ \\
\hline Marumbi & 0.80 & 321 & 29 & 2.915 & 4,012 & 35.2 & 35.6 & 8.7 & 9.0 & 5.2 & 2 & $\mathrm{HA}$ \\
\hline Anhang. - 1300 & 0.16 & 706 & 25 & 2.220 & 4,418 & 29.3 & 31.9 & 8.0 & 7.0 & 3.5 & 1 & $\mathrm{HA}$ \\
\hline Anhang. - 1200 & 0.26 & 564 & 43 & 3.180 & 2,169 & 41.3 & 49.6 & 13.4 & 14.0 & 5.0 & 3 & LA \\
\hline Serra Fina - VP & 0.10 & 191 & 14 & 2.048 & 1,910 & 41.5 & 54.4 & 14.7 & 13.0 & 7.0 & 1 & $\mathrm{HA}$ \\
\hline Serra Fina - FO & 0.10 & 263 & 15 & 1.951 & 3,160 & 20.7 & 26.3 & 8.3 & 7.0 & 3.6 & 1 & $\mathrm{HA}$ \\
\hline Serra Fina - MN & 0.10 & 197 & 14 & 2.047 & 1,970 & 32.0 & 48.9 & 12.5 & 12.0 & 6.6 & 1 & $\mathrm{HA}$ \\
\hline M. Verde - 1900 & 0.15 & 503 & 47 & 2.980 & 3,353 & 39.6 & 52.2 & 10.6 & 12.0 & 5.9 & 2 a 1 & LA \\
\hline M. Verde - 1800 & 0.20 & 688 & 53 & 3.110 & 3,440 & 38.9 & 84.3 & 10.0 & 14.0 & 6.6 & 3 & LA \\
\hline Camanducaia & 0.75 & 1,501 & 58 & 2.900 & 2,001 & 48.1 & 130.0 & - & 22.0 & 11.0 & 3 & LA \\
\hline
\end{tabular}


Table 5. Five species with the highest importance values in the Atlantic upper montane forests (AUMF) in the southern and southeastern regions of Brazil. MI-SC and RR-SC, Falkenberg (2003); MB-PR, Rocha (1999); AH1-PR and AH2-PR, Roderjan (1994); MV-MG, Meireles et al. (2008); CD-MG, França \& Stehmann (2004); SF-MG: this sample.

\begin{tabular}{|c|c|c|c|c|c|}
\hline Surveys & $1^{\mathrm{a}} \mathrm{IV}$ & $2^{\mathrm{a}} \mathrm{IV}$ & $3^{\mathrm{a}} \mathrm{IV}$ & $4^{\mathrm{a}} \mathrm{IV}$ & $5^{\mathrm{a}} \mathrm{IV}$ \\
\hline $\begin{array}{l}\text { Morro da Igreja } \\
\text { MI-SC }\end{array}$ & $\begin{array}{l}\text { Myrceugenia } \\
\text { ovata }\end{array}$ & $\begin{array}{l}\text { Drimys } \\
\text { angustifolia }\end{array}$ & $\begin{array}{c}\text { Crinodendron } \\
\text { brasiliense }\end{array}$ & $\begin{array}{l}\text { Maytenus } \\
\text { boaria }\end{array}$ & $\begin{array}{l}\text { Weinmannia } \\
\text { humilis }\end{array}$ \\
\hline $\begin{array}{l}\text { Rio do Rastro } \\
\text { RR-SC }\end{array}$ & $\begin{array}{l}\text { Siphoneugena } \\
\text { reitzii }\end{array}$ & $\begin{array}{l}\text { Ilex } \\
\text { microdonta }\end{array}$ & $\begin{array}{c}\text { Ocotea } \\
\text { pulchella }\end{array}$ & $\begin{array}{l}\text { Myrceugenia } \\
\text { alpigena }\end{array}$ & $\begin{array}{l}\text { Myrceugenia } \\
\text { glaucescens }\end{array}$ \\
\hline $\begin{array}{l}\text { Marumbi } \\
\text { MB-PR }\end{array}$ & $\begin{array}{c}\text { Ocotea } \\
\text { catharinensis }\end{array}$ & $\begin{array}{c}\text { Ilex } \\
\text { microdonta }\end{array}$ & $\begin{array}{c}\text { Myrceugenia } \\
\text { seriato-ramosa }\end{array}$ & $\begin{array}{c}\text { Siphoneugena } \\
\text { reitzii }\end{array}$ & $\begin{array}{c}\text { Eugenia } \\
\text { neomyrtifolia }\end{array}$ \\
\hline $\begin{array}{l}\text { Anhangava-1 } \\
\text { AH1-PR }\end{array}$ & $\begin{array}{c}\text { Ilex } \\
\text { microdonta }\end{array}$ & $\begin{array}{l}\text { Siphoneugena } \\
\text { reitzii }\end{array}$ & $\begin{array}{l}\text { Blepharocalyx } \\
\text { salicifolius }\end{array}$ & $\begin{array}{c}\text { Drimys } \\
\text { brasiliensis }\end{array}$ & $\begin{array}{l}\text { Weinmannia } \\
\text { humilis }\end{array}$ \\
\hline $\begin{array}{l}\text { Anhangava-2 } \\
\text { AH2-PR }\end{array}$ & $\begin{array}{c}\text { Ocotea } \\
\text { catharinensis }\end{array}$ & $\begin{array}{l}\text { Weinmannia } \\
\text { humilis }\end{array}$ & $\begin{array}{l}\text { Siphoneugena } \\
\text { reitzii }\end{array}$ & $\begin{array}{c}\text { Ilex } \\
\text { microdonta }\end{array}$ & $\begin{array}{l}\text { Critoniopsis } \\
\text { quinqueflora }\end{array}$ \\
\hline $\begin{array}{l}\text { Monte Verde } \\
\text { MV-MG }\end{array}$ & $\begin{array}{c}\text { Pimenta } \\
\text { pseudocaryophyllus }\end{array}$ & $\begin{array}{l}\text { Roupala } \\
\text { rhombifolia }\end{array}$ & $\begin{array}{c}\text { Drimys } \\
\text { brasiliensis }\end{array}$ & $\begin{array}{l}\text { Miconia } \\
\text { cinerascens }\end{array}$ & $\begin{array}{l}\text { Myrceugenia } \\
\text { myrcioides }\end{array}$ \\
\hline $\begin{array}{l}\text { Camanducaia } \\
\text { CD-MG }\end{array}$ & $\begin{array}{c}\text { Ocotea } \\
\text { lancifolia }\end{array}$ & $\begin{array}{l}\text { Cabralea } \\
\text { canjerana }\end{array}$ & $\begin{array}{l}\text { Psychotria } \\
\text { velloziana }\end{array}$ & $\begin{array}{l}\text { Myrcia } \\
\text { fallax }\end{array}$ & $\begin{array}{c}\text { Drimys } \\
\text { brasiliensis }\end{array}$ \\
\hline $\begin{array}{l}\text { Serra Fina } \\
\text { SF-MG }\end{array}$ & $\begin{array}{l}\text { Myrsine } \\
\text { gardneriana }\end{array}$ & $\begin{array}{l}\text { Myrceugenia } \\
\text { alpigena }\end{array}$ & $\begin{array}{l}\text { Weinmannia } \\
\text { humilis }\end{array}$ & $\begin{array}{l}\text { Symplocos } \\
\text { corymboclados }\end{array}$ & $\begin{array}{c}\text { Symphyopappus } \\
\text { itatiaiensis }\end{array}$ \\
\hline
\end{tabular}

spp.), Solanum (07 spp.), Symplocos (08 spp.), Vernonanthura (06 spp.), Tibouchina (04 spp.), and Weinmannia (04 spp.) are the most species rich genera in AUMFs.

\section{Discussion}

AUMFs of PCAM demonstrated typical features of cloud forests, such as high stem density, less-developed stem diameter, low canopy height, low species richness, and a high proportion of multi-stemmed individuals at breast height (Hamilton et al. 1995; Falkenberg \& Voltolini 1995; Meireles et al. 2008). Most of the sampled species in PCAM had narrow geographical distributions and occurred only in forest formations of high-altitude mountain ranges in the southern and southeastern region of Brazil, whereas other species were endemic to the Itatiaia Plateau, which is a typical feature of forests under the influence of clouds (Hamilton et al. 1995).

Regardless of the fact that the three PCAM forest sites were located at similar altitudes, they showed some physiognomic and structural differences. They showed low diversity, but the differences in diversity indices suggest that FO is be a more restrictive area for the occupation of some tree species than MN and VP. Some species were sampled in only one of these sites, but the greatest difference in horizontal structure between them was related to the abundance of the most important species. These differences could be associated with local abiotic conditions, occupation history, successional stages, and biotic factors related to the niche of species that influence the interspecific competition and the establishment of those tree species (Wright 2002).

The main physiognomic differences among the forest sites were related to canopy height and the number of stems per individual. FO had the lowest average and maximum height of trees. The height of the first trunk bifurcation was visually lower in FO than in VP and MN. Meireles et al. (2008) found a lower forest stature in areas most exposed to the winds in the same mountain range; however, the soil depth may be the main factor explaining the lower stature of trees in FO in the Serra Fina mountain range, although we do not have any information about soil depth in those areas to confirm this hypothesis. These forest sites did not display differences in the proportion of multi-stemmed individuals at breast height. However, in FO, the number of stems per individual was significantly higher than in VP and $\mathrm{MN}$. In fact, the survey in FO included a forest site border that was in contact with high-altitude grassland areas, wherein some shrubs species occur, promoting the main floristic dissimilarities with VP and MN.

Physiognomic differences between PCAM forests sites could be associated with variations in the architecture of the most abundant species. The high abundance of multistemmed individuals in FO is partly related to the high abundance of $M$. gardneriana. The number of stems in individuals of $M$. gardneriana in FO was higher than in $\mathrm{VP}$ and in MN. This was observed more in M. alpigena and Roupala rhombifolia individuals in FO than in VP and MN. Architectural differences between species could be related to a growth trade-off between the gain in height and lateral diffusion (Archibald \& Bond 2003). Species with a wide geographical distribution might display some architectural phenotypic plasticity in response to different environmental pressures (Pohlman et al. 2005). Abe \& Yamada (2008) have found that Symplocos species occurring in high-altitude Asian montane forests had thinner stems, and crowns that were more closely arranged, possibly to obtain mechanical stability. Trees with multiple stems increase the possibility of obtaining more light 
and have advantages in the occurrence of physical damage (Falkenberg 2003). In AUMFs, the high incidence of multiple-stemmed trees may also be associated with mechanical stability in shallow soils or resistance to strong winds. In addition, multiple stems could be a strategy in response to the occurrence of frosts, which could affect the most exposed apical meristems.

The standing-up dead biomass usually has high importance values in AUMFs (Meireles et al. 2008; Falkenberg 2003). Falkenberg (2003) suggested that the persistence of standing-up dead individuals in the cloud forests is related to the low decomposition rate of organic matter compared to ombrophilous forests at lower altitudes. In another surveys of Serra Mantiqueira, the importance of standing dead biomass could be explained by the high amount of dead tree biomass, suggesting a mechanical limit for tree survival in high-altitude areas (Meireles et al. 2008). The greater exposure to mechanical and climate damage factors, such as differences in exposure to wind, soil depth, drainage patterns, and topography could be associated with mortality in high-altitude areas; however, these are generalizations that need to be tested (Arriaga 2000; Bellingham \& Tanner 2000).

In PCAM forest sites, the massive mortality of bamboo clumps in the recent past has resulted in a large amount of dead biomass that has fallen into the understory and tree strata. This bamboo is most likely Chusquea leptophylla, for which there is no phenological information (Clark 2001). Some bamboo seedlings were observed in August 2007. The dead bamboo clumps fell onto the crowns of tree and shrubs, breaking or damaging some of the trees, and even falling into areas previously occupied by the same clumps. This promotes an increase in light in the forest understory and opening gaps of different sizes. The dynamic created by the dead clumps and the re-establishment of new bamboo individuals, and its effect on the tree seedling and understory species remains a phenomenon to be studied because of the phytosociological importance of bambusoides species in AUMFs (Stern et al. 1999; Meireles et al. 2008).

AUMF analyzed showed lower richness (S), effective number of species $\left(\mathrm{D}_{\mathrm{H}^{\prime}}\right)$, and diversity $\left(\mathrm{H}^{\prime}\right)$ than $\mathrm{AMF}$ in the Atlantic Plateau of São Paulo state and tended to have higher total density per hectare (DE) and total dominance per hectare (DO). Along altitudinal gradients, forests generally display both an increase in density of individuals and basal area and a decrease in species richness, canopy height, and tree diameter with an increase in elevation (Kitayama 1992; Givnish 1999). Rodrigues et al. (1989) related the structural changes of seasonal forests to physical and chemical soil characteristics along the altitudinal gradient. Some AMF studies conducted above 1,000 m.a.s.l. (Serra do Japi and Serra do Itapety) showed densities similar to those found in AUMF. However, AMFs at lower altitudes in more restrictive areas show greater tree species richness. Moreover, AUMFs had higher avascular or vascular epiphytism associated with the presence of fog and this could be another feature to differentiate them (Falkenberg \& Voltolini 1995; Hamilton et al. 1995; Meireles et al. 2008).

The lower richness and diversity index in AUMFs suggest more restrictive environmental conditions in highaltitude areas than forests at middle altitudes (Scarano 2002). In more restrictive environmental conditions, the species that are best adapted to the local ecological conditions can dominate the community, showing a discrepancy in abundance in relation to other species (Kitayama 1992). The Simpson index was higher for PCAM surveys than for AUMF of Monte Verde in the same mountain range (Meireles et al. 2008). This suggests a higher concentration of individuals within a few species as altitude increases (Martins \& Santos 1999). In PCAM forest sites $(\mathrm{D}=0.146)$, three species accounted for $51.5 \%$ of the total standing individuals. In Monte Verde ( $\mathrm{D}=0.059)$, which is approximately 300 meters lower in altitude, six species accounted for $51.9 \%$ of individuals at 1,900 m.a.s.l., and eight species accounted for $49.9 \%$ of individuals at 1,800 m.a.s.l. (Meireles et al. 2008). This high concentration of individuals within a few species suggests an oligarchic community structure for AUMFs (Scarano 2002).

In MI-SC and RR-SC, only two species accounted for approximately $80 \%$ of the total density (Falkenberg 2003). The effective number of species among AUMFs showed that the "Aparados da Serra" (MI-SC) and "Serra do Rio do Rastro" (RR-SC) surveys had the lowest estimated richness, whereas AUMFs at lower altitudes (MV-MG and CD-MG, $\mathrm{AH} 2-\mathrm{PR}$ and $\mathrm{MB}-\mathrm{PR}$ ) had greater richness than surveys in the higher altitudes in Serra Fina (SF-MG) and Morro do Anhangava (AH1-PR). The lower richness that occured in "Aparados da Serra" and "Serra do Rio do Rastro" may be related to a decrease in tree species richness towards higher latitudes versus the regional altitudinal gradient, which is promoted by lower minimum temperatures and increasing frost events in the southern region (Nimer 1977b; OliveiraFilho \& Fontes 2000).

Among AUMF surveys, several of the analyzed structural parameters overlapped, which made it difficult to use a classification system based only on physiognomy and structural parameters. AUMFs showed high variation in canopy height, suggesting that this parameter alone should not be used to identify those forests. AUMFs at higher altitude with low canopy height had higher variation in dominance, whereas AUMFs at lower altitude with higher canopy height varied in density. Sub-divisions based on the physiognomy of montane forest formations have been related to the frequency and intensity of fog (Bruijnzeel \& Veneklaas 1998). Grubb \& Whitmore (1966) suggested that tropical montane forests with higher canopy have a lower frequency of fog than forests with lower canopy. AUMFs with low canopy height have been observed in the more restrictive areas with extreme altitudinal gradients (Meireles et al. 2008; Roderjan 1994; Bertoncello et al. 2011). But a 
gradual variation in the canopy height could be observed along the altitudinal gradients in the southern and southeastern coastal Brazilian mountain ranges along the same floristic belt (Meireles et al. 2008; Roderjan 1999).

Cloud forests could be regarded as a physiognomy of upper montane forest belts and their structural differences could be associated with a gradient of climatic changes related to altitude increase, topography, and soil depth characteristics (Segadas-Viana \& Dau 1965; Whitmore \& Burnham 1984; Cavalier \& Goldstein 1989). The regional topographic conditions, length of altitudinal gradient, and distance to ocean could be the main factors associated with the variation of physiognomy observed between upper montane forests in the southern and southeastern regions of Brazil. Two situations have been described: (1) Typical cloud forests correspond to upper montane forest, with a reduced structure in flat areas in "Aparados da Serra" in the southern region (Falkenberg 2003). Alternatively (2), where typical cloud forests occur as a narrow belt inside an upper montane forest, such as occurs in the Serra da Mantiqueira mountain range and in the Serra do Mar in the states of Paraná and São Paulo (Roderjan 1999; Meireles et al. 2008; Bertoncello et al. 2011). A combination of the definitions by Veloso \& Góes (1982) and Veloso (1992) for AUMF could be utilized to define forests that are influenced by clouds or fog in high-altitude areas. These definitions together described the upper montane or the "superomontane" belts in the Atlantic Forest (Oliveira-Filho 2009). Therefore, AUMFs analyzed in the present study correspond to ombrophilous forests composed of high density and dominance, with a high frequency of multi-stemmed individuals at breast height, and with a canopy height ranging from 7 to 20 meters.

On a global scale, tropical montane cloud forests show a significant variation in altitude; they can occur within the montane and sub-montane vegetation belts and do not have a fixed lower altitudinal limit for its occurrence (Stadtmüller 1987; Bruijnzeel \& Veneklaas 1998; Hamilton et al. 1995; Doumenge et al. 1995). The classification in "Brazilian Vegetation Systems" provides an altitude range according to latitude to distinguish forest formations (Veloso 1992). However, the range of the upper montane forest belt and its lower altitudinal limit depends on the geographical position of mountain range, regional physiographic conditions, range of the regional altitudinal gradient, and distance to the ocean, which are factors that affect the occurrence and frequency of fog. The soil depth and micro topographical conditions allow for the establishment of forests inside mountain ranges, as occurs in Brazilian mountain ranges where a tree line is not observed (Hueck 1972).

In addition to structural similarities, AUMFs of the Serra da Mantiqueira mountain range in the southeastern region and AUMFs of the Serra do Mar mountain range in the southern region were very similar at the family, genera, and species levels (Meireles 2009). In the AMF of the Atlantic Plateau of São Paulo state, the species with the highest importance values belonged to 36 genera in the same geographical region (Dislich et al. 2001); and in AUMF, the most important species belonged to 20 genera. The most important families in AUMF usually are represented by few species or individuals in the tree strata of forest formations at middle and lower altitudes, like Asteraceae, Aquifoliaceae, Cunoniaceae, Escalloniaceae, Myrsinaceae, Proteaceae, Symplocaceae, and Winteraceae (Koehler et al. 2002; Meireles et al. 2008; Scheer et al. 2011).

Myrtaceae, the most species rich family in the Atlantic Rain Forest, is also one the most species rich in AUMF, with a high relatively density (Oliveira-Filho \& Fontes 2000; Yamamoto et al. 2005; Meireles et al. 2008). The family Lauraceae, was absent from the PCAM forest sites, but some species from this family have been recorded in AUMF at intermediate altitudes. The families Proteaceae and Winteraceae had less phytosociologic importance in the Serra Fina, whereas Symplocaceae and Cunoniaceae had a higher importance. This is a very similar pattern with other tropical montane cloud forests (Madsen \& Ollgaard 1994; Kelly et al. 1994; Hamilton et al. 1995). Fabaceae, one the most species rich families, mainly occurs in the seasonal and ombrophilous forests at lower altitudes, showed the lowest phytosociologic importance in AUMF (Yamamoto et al. 2005; Meireles et al. 2008; Punyasena et al. 2008).

At the genus level, AUMF showed similarities to the Andean montane forests and, shared some genera with Central American cloud forests (Falkenberg \& Voltolini 1995; LunaVega et al. 2001). The most rich genera, or genera with the most phytosociological importance, may be not present in all areas where AUMF occur. Furthermore, this importance varies by regional scale and along altitudinal gradients. Some pantropical genera sampled in AUMF are present in tropical montane cloud forests around the world, like Clethra, Myrsine, Prunus, and Symplocos (Ohsawa 1991, Mabberley 1998; Madsen \& Ollgaard 1994; Merlin \& Juvik 1995; Kitayama 1995). Others are neotropical genera, with species that can either be unique to the upper montane forests, or be tolerant to adverse high-altitude environmental conditions and have a broad geographical distribution throughout Atlantic Forests, like Euplassa, Leandra, Miconia, Pimenta, Roupala, and Siphoneugena (Mabberley 1998; Oliveira-Filho \& Fontes 2000; Meireles et al. 2008).

Some neotropical genera like Baccharis, Chusquea, Crinodendron, Critoniopsis, and Dasyphyllum are also the richest genera in the Andean Cordillera (Cabrera 1959; Smith \& Smith 1970; King \& Robinson 1987; Soderstrom et al. 1987; Müller 2006). Azara, Drimys, Escallonia, Myrceugenia, Podocarpus, and Weinmannia are Austral-Antarctic genera that represent the temperate element in the tree strata in AUMFs. These genera are the most rich in Andean forests, and most species are restricted to montane forests in the Atlantic Forest (Sleumer 1980; Giulietti \& Pirani 1988; Lima et al. 2005; Landrum 1981; Safford 2007). Macropeplus and Symphyopappus are exclusive At- 
lantic genera and most of their species occur in montane forests or in high-altitude grasslands (King \& Robinson 1987; Santos \& Peixoto 2005).

Similarities in annual precipitation and annual mean temperatures, incidence of frosts, and high incidence of clouds may be observed among high-altitude areas of southern and southeastern Brazil are responsible for part of the floristic similarities in these AUMFs despite their discontinuous geographic distribution (Meireles 2009; Bertoncello et al. 2011). This floristic similarity is also influenced by the lower number of Atlantic Forest species that are able to tolerate the more restrictive conditions of high-altitude areas. In southeastern Brazil, the Serra da Mantiqueira mountain range plays a very important role in floristic placement along the altitudinal gradient in the Atlantic Forest, since this is an inland mountain range and it receives less influence from the Atlantic tropical flora. This is due to the more temperate climates of their highaltitude areas (Segadas-Viana \& Dau 1965; Nimer 1977a). There is a similar occurrence in the coastal mountains of the southern region, which despite receiving greater influence from coastal air masses, their high-altitude areas are cooler due to the effect of latitude (Nimer 1977b).

Many species that belong to the Austral-Antarctic and tropical genera that occur mainly in high-altitude areas are related with these floristic similarities. The past climate change events in the late Quaternary period may also be involved in an explanation of this similarity. This has created particular phytogeographical patterns that are explained by the climatic niche of these species and Quaternary climate changes (Behling 1998; Behling 2002; Meireles 2009). Palynological records show that taxa currently restricted to high-altitude areas in the southeastern region occurred at middle altitudes and may have expanded via the Brazilian Plateau near the time of the Last Glacial Maximum (Pessenda et al. 2009; Oliveira et al. 2005). The cold and wet period that occurred near the time of the Last Glacial Maximum could have been the last time that the montane forest vegetation of the southern and southeastern regions of Brazil had greater contact (Meireles 2009). Additionally, this may have favored the dispersal of these species.

The distinctive climatic and physiographic conditions at the top of mountains strongly influence the forest structure that occurs there. The conditions along the altitudinal gradients gradually restrict the establishment of tree species, influencing the floristic composition and structure of these forests and the physiognomic variations that are related to density, dominance, canopy height, and the architecture and diameter of trees (Doumenge et al. 1995). Although the structure and physiognomy of mountain forests under the influence of fog are characteristic, there is no single environmental factor to explain the unmistakable characteristics of these forests, except the frequency of low cloud (Bruijnzeel \& Veneklaas 1998). Abiotic, biotic, physiological, and forest dynamics hypotheses have been proposed to explain the structure and functioning of cloud forests, but they are not mutually exclusive (Stadtmüller 1987; Bruijnzeel \& Veneklaas 1998).

AUMFs occupy a fragmented and small area, but they contain a large number of species that have a narrow geographic distribution and are restricted to adverse conditions of high-altitude areas. Despite the lower species richness in these forests, the specificity of the climate that the species are subjected to allows for the occurrence of endemic species throughout their geographic distribution range. There are still areas in upper montane forests where no floristic or phytosociological surveys have been conducted. The knowledge of the flora in these regions and other inland mountains ranges can bring new insights to the species distribution of forests under the influence of fog in the Atlantic Forest Domain.

Unfortunately, those forests are good candidates for studies involving changes in vegetation associated with global warming. Their unusual and discontinuous geographical distribution and the presence of endemic taxa emphasizes the biological and biogeographical importance of these forests. Due to the important role these forest ecosystems play, an effort to locate and describe new areas of upper montane forests in the Atlantic Forest Domain should be continued in an effort to contribute to the conservation of these forests.

\section{Acknowledgments}

We thank the Fundação de Amparo à Pesquisa do Estado de São Paulo for a research grant (FAPESP Proc. 04/10110-9) and financial support (FAPESP Proc. 05/60862-0). Thanks to José Augusto Nunes, José de O. Costa Neto for their guidance and support in the field and the taxonomists of BHCB, UEC, SPF and Ribeirão Preto for species identification. Thanks to Luciana Alves, Tiago Duque Estrada, and Igor A. Silva (in memoriam) for comments.

\section{References}

Abe N, Yamada T. 2008. Variation in allometry and tree architecture among Symplocos species in a Japanese warm-temperate forest. Journal of Plant Research 121: 155-162.

Archibald S, Bond WJ. 2003. Growing tall vs. growing wide: tree architecture and allometry of Acacia karroo in forest, savanna, and arid environments. Oikos 102: 3-14.

Arriaga L. 2000. Types and causes of tree mortality in a tropical montane cloud forest of Tumaulipas, Mexico. Journal of Tropical Ecology 16: 623-636.

Ayres M, Ayres Jr M, Ayres DL, Santos AS. 2007. BioEstat 5.0: aplicações nas áreas das ciências biológicas e médicas. Belém, Sociedade Civil Mamirauá.

Behling H. 1998. Late quaternary vegetational and climatic changes in Brazil. Review of Palaeobotany and Palynology 99: 143-156.

Behling H. 2002. South and southeast Brazilian grasslands during Late Quaternary times: a synthesis. Palaeogeography, Palaeoclimatology, Palaeoecolgy 177: 19-27.

Bellingham PJ, Tanner EVJ. 2000. The influence of topography on tree growth, mortality, and recruitment in a tropical montane forest. Biotropica 32: 378-384.

Bertoncello R, Yamamoto K, Meireles LD, Shepherd GJ. 2011. A phytogeographic analysis of cloud forests and other forest subtypes amidst the Atlantic forest in south and southeast Brazil. Biodiversity and Conservation 20: 3413-3433. 
Bruijnzeel LA, Proctor J. 1995. Hydrology and biogeochemistry of tropical montane cloud forest: what do we really know? In: Hamilton LS, Juvik JO, Scatena FN. (eds.) Tropical montane cloud forests. New York, Springer-Verlag. p.38-79.

Bruijnzeel LA, Venaklaas EJ. 1998. Climatic conditions and tropical montane forest productivy: the fog has not lifted yet. Ecology 79: 3-9.

Cabrera AL. 1959. Revision del genero Dasyphyllum (Compositae). Revista del Museo de La Plata 9: 1-100.

Carvalho LMT, Fontes MAL, Oliveira-Filho AT. 2000. Tree species distribution in canopy gaps and mature forest in a area of cloud forest of the Ibitipoca Range, south-eastern Brazil. Plant Ecology 149: 9-22.

Cavalier J, Goldstein G. 1989. Mist and fog interpretation in elfin cloud Forest in Colombia and Venezuela. Journal of Tropical Ecology 5: 309-322.

Chiessi CM. 2004. Tectônica cenozóica do Maciço Alcalino de Passa Quatro (SP-MG-RJ). Msc Thesis, Universidade de São Paulo, Brazil.

Clark LG. 2001. Chusquea. In: Wanderley MGL, Shepherd GJ, Giulietti AM. (eds.) Flora Fanerogâmica do Estado de São Paulo. Vol 1. São Paulo, Fapesp, Hucitec. p. 24-36.

Dislich R, Cersósimo L, Mantovani W. 2001. Análise da estrutura de fragmentos florestais no Planalto Paulistano - SP. Revista Brasileira de Botânica 24: 321-332.

Doumenge C, Gilmour D, Perez MR, Blockhus J. 1995. Tropical montane cloud forests: conservation status and management issues. In: Hamilton LS, Juvik JO, Scatena FN. (eds.) Tropical montane cloud forests. New York, Springer-Verlag. p. 24-37.

Falkenberg DB. 2003. Matinhas nebulares e vegetação rupícola dos Aparados da Serra Geral (SC/RS), sul do Brasil. PhD Thesis, Universidade Estadual de Campinas, Brazil.

Falkenberg DB, Voltolini JC. 1995. The montane cloud forest in Southern Brazil. In: Hamilton LS, Juvik JO, Scatena FN. (eds.). Tropical montane cloud forests. New York, Springer-Verlag. p. 138-149.

Flenley JR. 1995. Cloud forest, the Massenerhebung effect, and ultraviolet insolation. In: Hamilton LS, Juvik JO, Scatena FN. (eds.). Tropical montane cloud forests. New York, Springer-Verlag. p. 150-155.

França GS, Stehmann JR. 2004. Composição florística e estrutura do componente arbóreo de uma floresta altimontana no município de Camanducaia, Minas Gerais, Brasil. Revista Brasileira de Botânica 27: 19-30.

Gioda A, Maley J, Guasp RE, Baladón AA. 1995. Some low elevation fog forests of dry environments: applications to African paleoenvironments. In: Hamilton LS, Juvik JO, Scatena FN. (eds.). Tropical montane cloud forests. New York, Springer-Verlag. p.156-164.

Giulietti AM, Pirani JR. 1988. Patterns of geographic distribution of some species from the Espinhaço Range, Minas Gerais and Bahia, Brasil. In: Vanzolini PE, Heyer WR. (eds.). Proceedings of a Workshop on Neotropical Distribution Patterns. Rio de Janeiro, Academia Brasileira de Ciências. p. 39-69.

Givnish TJ. 1999. On the causes of gradients in tropical tropical tree diversity. Journal of Ecology 87: 193-210.

Grubb PJ, Whitmore TC. 1966. A comparison of montane and lowland rain forest in Ecuador. II. The climate and its effects on the distribution and physiognomy of the forests. Journal of Ecology 54: 303-333.

Hamilton LS, Juvik JO, Scatena FN. 1995. The Puerto Rico tropical cloud forest symposium: introduction and workshop synthesis. In: Hamilton LS, Juvik JO, Scatena FN. (eds.). Tropical montane cloud forests. New York, Springer-Verlag. p. 1-23.

Hill MO. 1973. Reciprocal averaging: an eigenvector method of ordination. Journal of Ecology 61: 237-249.

Hueck K. 1972. As Florestas da América do Sul. Brasília, Editora da Universidade de Brasília.

Jost L. 2006. Entropy and diversity. Oikos 113: 363-375.

Juvik JO, Nullet D. 1995. Relationships between rainfall, cloud-water interception, and canopy throughfall in a Hawaiian montane forest. In: Hamilton LS, Juvik JO, Scatena FN. (eds.). Tropical montane cloud forests. New York, Springer-Verlag. p. 165-182.

Kelly DL, Tanner EVJ, Nic-Lughada EM, Kapos V. 1994. Floristic and biogeography of a rain forest in the Venezuelan Andes. Journal of Biogeography 21: 421-440.

King RM, Robinson H. 1987. The genera of the Eupatoriae (Asteraceae). Monographs in Systematic Botany. Missouri Botanical Garden 22: $1-581$.
Kitayama K. 1992. An altitudinal transect study of the vegetation on Mont Kinabalu, Borneo. Vegetatio 102: 149-171.

Kitayama K. 1995. Biophysical conditions of the montane cloud forests of Mount Kinabalu. In: Hamilton LS, Juvik JO, Scatena FN. (eds.) Tropical montane cloud forests. New York, Springer-Verlag. p. 183-197.

Koehler A, Galvão F, Longhi SJ. 2002. Floresta ombrófila densa altomontana: aspectos florísticos e estruturais de diferentes trechos na Serra do Mar, PR. Ciência Florestal 12: 27-39.

Landrum LR. 1981. A monograph of the genus Myrceugenia (Myrtaceae) Flora Neotropica 29: 1-137.

Lawton RO. 1982. Wind stress and elfin stature in a montane rain forest tree: an adaptive explanation. American Journal of Botany 69: 1224-1230.

Lima MIRG, Souza VC, Rodrigues RR. 2005. Grossulariaceae. In: Wanderley MGL, Shepherd GJ, Melhem TS, Giulietti AM. (eds.) Flora Fanerogâmica do Estado de São Paulo. Vol. 4. São Paulo, Fapesp, Rima. p. 223-225.

Luna-Vega I, Morrone JJ, Ayala OA, Organista DE. 2001. Biogeographical affinities among Neotropical cloud forests. Plant Systematics and Evolution 228: 229-239.

Mabberley DJ. 1998. The Plant-Book: a portable dictionary of the vascular plants. 2nd. edn. Cambridge, Cambridge University Press.

Madsen JE, Ollgaard B. 1994. Floristic composition, structure, and dynamics of an upper montane rain forest in Southern Ecuador. Nordic Journal of Botany 14: 403-423.

Magurran AE. 1988. Ecological diversity and its measurement. Princeton, Princeton University Press.

Martins CS. 2000. Caracterização física e fitogeográfica de Minas Gerais. In: Mendonça MP, Lins LV. (eds.) Lista vermelha das espécies ameaçadas de extinção da flora de Minas Gerais. Belo Horizonte, Fundação Biodiversitas. p. 35-43.

Martins FR, Santos FAM. 1999. Técnicas usuais de estimativa da biodiversidade. Revista Holos, edição especial 236-267.

McCune B, Grace JB. 2002. Analysis of Ecological Communities. Oregon, MjM Software Design.

Meireles LD, Shepherd GJ, Kinoshita LS. 2008. Variações na composição florística e na estrutura fitossociológica de uma floresta ombrófila densa alto-montana na Serra da Mantiqueira, Monte Verde, MG. Revista Brasileira de Botânica 31: 559-574.

Meireles LD. 2009. Estudos florísticos, fitossociológicos e fitogeográficos em formações vegetacionais altimontanas da Serra da Mantiqueira Meridional, sudeste do Brasil. PhD thesis, Universidade Estadual de Campinas, Brazil.

Merlin MD, Juvik JO. 1995. Montane cloud forest in tropical Pacific: some aspects of their floristic, biogeography, ecology, and conservation. In: Hamilton LS, Juvik JO, Scatena FN. (eds.) Tropical montane cloud forests. New York, Springer-Verlag. p. 234-253.

Muller-Dombois D, Ellenberg H. 1974. Aims and methods of vegetation ecology. New York, John Wiley \& Sons.

Müller J. 2006. Systematics of Baccharis (Compositae-Astereae) in Bolivia, including an overview of the genus. Systematic Botany Monographs 6: 1-341.

Nimer E. 1977a. Clima. In: Fundação Instituto Brasileiro de Geografia e Estatística (ed.). Geografia do Brasil: Região Sudeste. Rio de Janeiro, SERGRAF. p. 51-89.

Nimer E. 1977b. Clima. In: Fundação Instituto Brasileiro de Geografia e Estatística (ed.). Geografia do Brasil: Região Sul. Rio de Janeiro, SERGRAF. p. 35-79.

Ohsawa M. 1991. Structural comparison of tropical montane rain forest along latitudinal and altitudinal gradients in south and east Asia. Vegetatio 97: 1-10.

Oliveira PE, Behling H, Ledru MP, et al. 2005. Paleovegetação e paleoclimas do Quaternário do Brasil. In: Souza CLG, Suguio K, Oliveira AMS, Oliveira PE. (eds.). Quaternário do Brasil. Ribeirão Preto, Holos. p. 52-74.

Oliveira RS, Eller CB, Bittencourt PRL, Mulligan M. 2014. The hydroclimatic and ecophysiological basis of cloud forest distributions under current and projected climates. Annals of Botany 113: 909-920.

Oliveira-Filho AT. 2009. Classificação das fitofisionomias da América do Sul Cisandina Tropical e Subtropical: proposta de um novo sistema - prático e flexível - ou uma injeção a mais de caos? Rodriguésia 60: 237-258. 
Oliveira-Filho AT, Fontes MAL. 2000. Patterns of floristic differentiation among Atlantic Forest in southeastern Brazil and the influence of climate. Biotropica 32: 793-810.

Pessenda LCR, Oliveira PE, Moffato M, et al. 2009. The evolution of a tropical rainforest/grassland mosaic in southeastern Brazil since 28,000 ${ }^{14} \mathrm{C}$ yr BP based on carbone isotopes and pollen records. Quaternary Reserch 71: 437-452.

Pohlman CL, Nicotra AB, Murray BR. 2005. Geographic range size, seedling ecophysiology and phenotypic plasticity in Australian Acacia species. Journal of Biogeography 32: 341-351.

Portes MCGO, Galvão F. 2002. A floresta alto-montana do sul do Brasil: considerações climáticas, pedológicas e vegetacionais. Cadernos de Biodiversidade 3: 44-50.

Punyasena SW, Eshel G, McElwain JC. 2008. The influence of climate on the spatial pattern of Neotropical plant families . Journal of Biogeography $35: 117-130$.

Rambo B. 1949. A flora de Cambará. Anais Botânicos do Herbário Barbosa Rodrigues 1: 111-135.

Rocha MRL. 1999. Caracterização fitossociológica e pedológica de uma floresta ombrófila densa altomontana no Parque Estadual Pico do Marumbi - Morretes. PR. Msc Thesis, Universidade Federal do Paraná, Brazil.

Roderjan CV. 1994. A floresta ombrófila densa altomontana do Morro do Anhangava, Quatro Barras, PR - Aspectos Climáticos, Pedológicos e Fitossociológicos. PhD Thesis, Universidade Federal do Paraná, Brazil.

Rodrigues RR, Morellato, LPC, Joly CA, Leitão Filho HF. 1989. Estudo florístico e fitossociológico em um gradiente altitudinal de mata estacional mesófila semidecídua, na Serra do Japi, Jundiaí, SP. Revista Brasileira de Botânica 12: 71-84.

Safford HD. 1999. Brazilian Páramos I. An introduction to the physical environment and vegetation of the campos de altitude. Journal of Biogeography 26: 693-712.

Safford HD. 2007. Brazilian Páramos IV. Phytogeography of the campos de altitude. Journal of Biogeography 34: 1701-1722.

Santos IS, Peixoto AL. 2005. Taxonomia do gênero Macropeplus Perkins (Monimiaceae, Monimoideae). Rodriguésia 52: 65-105.

Scarano FR. 2002. Structure, function and floristic relationships of plant communities in stressful habitats marginal to the Brazilian Atlantic Rainforest. Annals of Botany 90: 517-524.

Scheer MB, Mocochinsky AY, Roderjan CV. 2011. Estrutura arbórea da Floresta Ombrófila Densa Altomontana de serras do Sul do Brasil. Acta Botanica Brasilica 25: 735-750.
Segadas-Viana F, Dau L. 1965. Ecology of the Itatiaia Range, Southeastern Brazil: II- Climates and altitudinal climatic zonation. Arquivos do Museu Nacional 53: 31-53.

Shepherd GJ. 2006. FITOPAC 1. Manual do usuário. Campinas, Departamento de Botânica, UNICAMP.

Silva JULE, Leite WCA. 2000. Distribuição do coeficiente de variação da pluviosidade na região oriental paulista. In: Anais do XXVII Congresso Interamericano de Engenharia Sanitária e Ambiental, 2000, Porto Alegre-RS. Rio de Janeiro, ABES. p. 1-8.

Sleumer HO. 1980. Flacourtiaceae. Flora Neotropica 22: 1-499.

Smith CE, Smith LB. 1970. Elaeocarpaceae. In: Reitz R. (ed.) Flora Ilustrada Catarinense. Itajaí, Herbário Barbosa Rodrigues.

Soderstrom TR, Judziewicz EJ, Clarck LG. 1987. Distribution patterns of neotropical bamboos. In: Vanzolini PE, Heyer WR. (eds.) Proceedings of a Workshop on Neotropical Distribution Patterns. Rio de Janeiro, Academia Brasileira de Ciências. p. 121-157.

Stadtmüller T. 1987. Cloud forests in the humid tropics. A bibliographic review. Costa Rica, United Nations University \& Centro Agronómico Tropical de Investigación Enseñanza.

Stern MJ, Goodell K, Kennard DK. 1999. Local distribution of Chusquea tomentosa (Poaceae:Bambusoideae) before and after a flowering event. Biotropica 31: 365-368.

Tubelis A, Nascimento FJL. 1980. Meteorologia descritiva: fundamentos e aplicações brasileiras. São Paulo, Nobel.

UNESCO- United Nations Educational, Scientific and Cultural Organization. 1973. International classification and mapping of vegetation. In: UNESCO (ed.). Ecology and conservation 6. Paris, UNESCO.

Veloso HP. 1992. Sistema Fitogeográfico. In: Instituto Brasileiro de Geografia e Estatística (ed.). Manual Técnico da Vegetação Brasileira. Rio de Janeiro, IBGE. p. 9-38.

Veloso H., Góes-Filho L. 1982. Fitogeografia brasileira: classificação fisionômico-ecológica da vegetação neotropical. Boletim Técnico do Projeto RADAMBRASIL (Série Vegetação) 1: 3-79.

Whitmore TC, Burnham CP. 1984. Tropical rain forests of the Far East. 2nd. edn. Oxford, Oxford University Press.

Wright SJ. 2002. Plant diversity in tropical forests: a review of mechanisms of species coexistence. Oecologia 130: 1-14.

Yamamoto LF, Kinoshita LS, Martins FR. 2005. Florística dos componentes arbóreo e arbustivo de um trecho da Floresta Estacional Semidecídua Montana, município de Pedreira, estado de São Paulo. Revista Brasileira de Botânica 28: 191-2002.

Zar JH. 1999. Biostatiscal analysis. 4th. edn. New Jersey, Prentice-Hall. 